
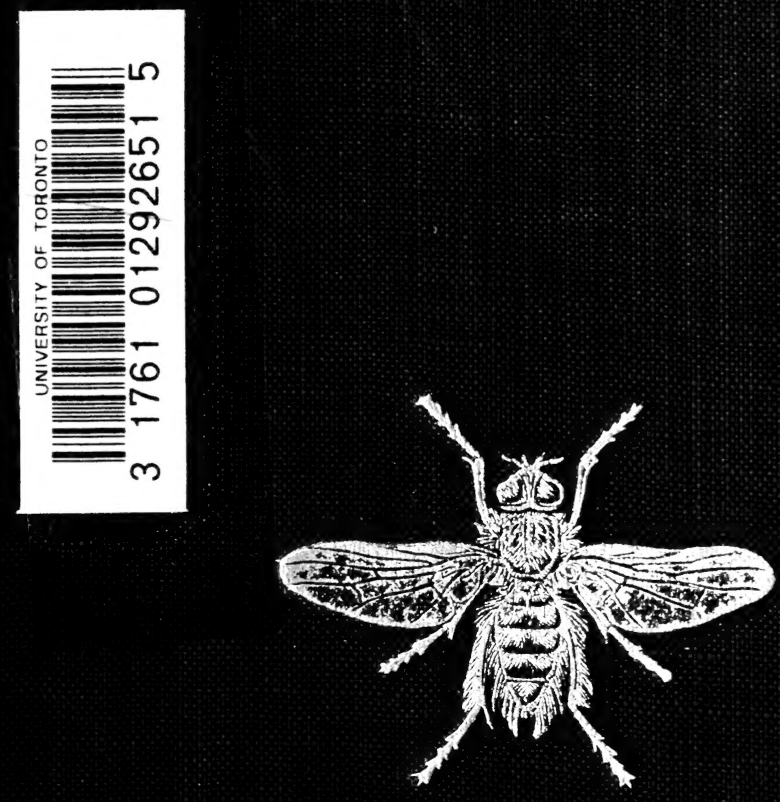

THE BOOK OF THE FLY 


\section{MICROBES AND TOXINS}

by DR. ETIENNE BURNET.

Preface by Professor E.

METCHNIKOFF

Illustrated, Cr. 8vo, 5/- net.

"It is one of those works which French authors seem to be especially skilful in producing-works which, while they treat their subject in the broadest possible way, and in a manner to interest the educated general reader as well as the specialist, and yet at the same time accurate and precise in detail."-Lancet .

London: William Heinemann 


\section{Zool}

Insecta

H

\section{THE BOOK OF \\ THE FLY}

A NATURE STUDY OF THE HOUSE-FLY AND ITS KIN, THE FLY PLAGUE AND A CURE

BY

G. HURLSTONE HARDY

With an Introduction by HALFORD ROSS.
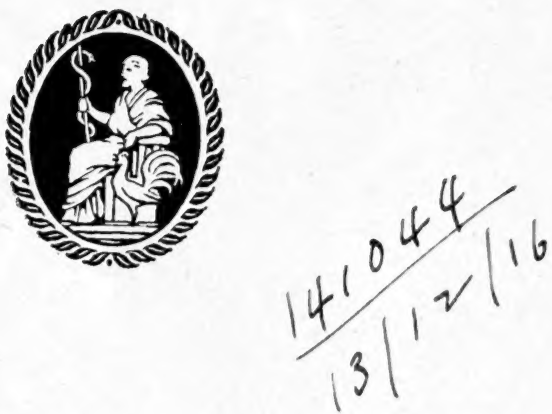

LONDON

WILLIAM HEINEMANN 
London: William Heinemann, 1915 


\section{CONTENTS}

CHAPTER

PAGE

PREFACE bY E. HALFORD ROSS, EsQ., M.R.C.S., L.R.C.P., \&C.

I. A Product of Human Insanitation $\ldots$...

II. IDENTIFICATION OF THE COMMON HOUSE-FLY $\ldots 7$

III. SOME OTHER FLIES AND THEIR DIVERSE HABITS I6

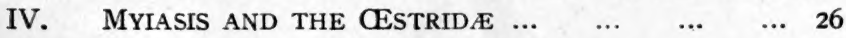

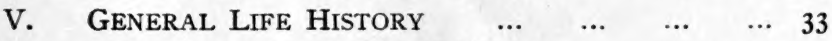

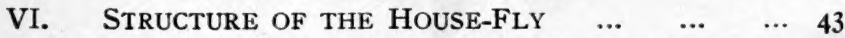

VII. Distribution and Concentration OF Flies $\ldots . \quad 49$

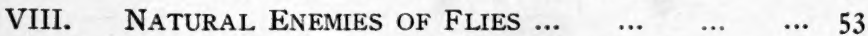

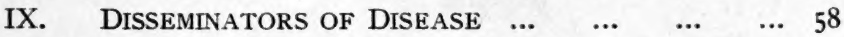

X. Remedial measures; Cremation of Refuse ... 64

XI. CONTROL Within THE HOUSE $\ldots$...

XII. SERVICE AND UTILITY OF Flies $\ldots . \quad \ldots \quad \ldots \quad 78$

XIII. A Campaign of Effective Warfare, Con$\begin{array}{llllllll}\text { CLUSION } & \ldots & \ldots & \ldots & \ldots & \ldots & \ldots & 84\end{array}$

\section{APPENDIX}

Description of the Wingate Fly Chart $\ldots 89$

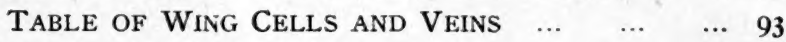

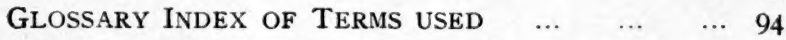

Alphabetical List of Sixty Families $\quad \ldots \quad$... 95

Numbered List OF FAMILIES WITH DEscriptive

NOTES AND REFERENCES ... $\quad \ldots \quad \ldots \quad \ldots \quad \ldots l 108$

Analytical Table of Families $\quad \ldots \quad \ldots \quad \ldots l 13$ 
Digitized by the Internet Archive in 2007 with funding from Microsoft Corporation 


\section{ILLUSTRATIONS}

Fig. I. The House-Fly, Female, Enlarged $\ldots . \quad \ldots \quad 6$

״ 2. The Lesser House-Fly, MaLe, Enlarged ... 6

„2a. The Stable-Fly, Female, Enlarged $\ldots . \quad \ldots \quad 6$

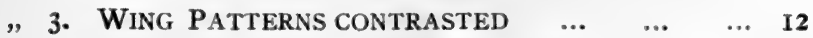

„ 5. Metamorphosis; LARVA, Instar, Imago $\quad$... 39

„6. Apparatus for the Bkeeding of Gentles 81

THE WINGATE FLY CHART (APPENDIX)

Plate I. External Parts and Characters, named 88

" II. ANTENNA, MANY-JOINTED TYPES $\quad \ldots \quad$... 97

” III. ANTENNÆ, THREE OR FEW-JOINTED TYPES ... 99

,, IV. WINGS, TYPE-FORMS OF NEMOCERA ... $\quad . .3$ 30I

„ V. WINGS, OTHER TYPE-FORMS $\quad \ldots \quad \ldots \quad \ldots \quad \ldots 103$

Details of Special Characteristics, etC. 105

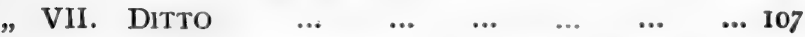

NOTE, Fig. 4 has been found to be not available for this edition. 



\section{PREFACE}

THE dangers of house-flies to the health of the community have come into such recent prominence that the appearance of Major Hurlstone Hardy's book should fill a want. It is written lucidly and clearly, yet in that popular style which is so frequently lacking in scientific works. This is a great advantage. Too often scientists are prone to bring out works couched in terms which cannot be understood by an interested public that is not versed in technical terms. Thus matter which is of the greatest general importance is passed unread by many, and is, in consequence, not acted upon.

Major Hardy has a knowledge of these deadly insects which, in my opinion, is unsurpassed, because he has the personal experience of practical experiment combined with the instincts of the naturalist. The result is an account both accurate and interesting which should prove of the greatest value.

The discovery of the transmission of disease by mosquitoes required the passage of a decade before its essentials were grasped by the public mind; that of the prevention of small-pox required a century. But the dangers of house-flies is rapidly becoming known in consequence of the popular literature, which is growing, describing the details of the lives of these loathly creatures. In this way only can such knowledge be spread-a knowledge which must become general before flies and the maladies they convey can be generally and satisfactorily dealt with. It is of little use to make great discoveries and then to hide them on the musty bookshelves of learned societies. 


\section{PREFACE}

Instead, they should be adapted to practical purposes applied for the good of suffering humanity; and the best way to do this is to bring out well-written, interesting, and easily read books of this kind, so that all who run may read and their readings endure. This book should assist much to accomplish this end. Thus we may look forward confidently to the day when house-flies, and the diseases they carry, are things of the past. The "Book of the Fly" must take its place in the history of the events which are to lead up to the winning of that goal.

HALFORD Ross

(of the John Howard McFadden Researches at the Lister Institute of Preventive Medicinc). 


\section{THE BOOK OF THE FLY}

\section{CHAPTER I}

THE HOUSE-FLY, A PRODUCT OF HUMAN INSANITATION

With the present day zeal for popularising interest in common things (called nature study) there has arisen the demand for knowledge practically useful and thoroughly up-to-date, yet in a form free from much of the technical terminology and treatment which are essential in the student's more fully developed scientific handbook.

The "House-fly" is a fit subject for a simplified study of this kind, and the present booklet is an attempt to afford information very different to that of the "popular" works, which only were accessible to the writer's hands between fifty and sixty years ago; the writers of those old books all followed the lead of the reverend and learned contributors to the famous and monumental "Bridgwater Treatises." "The Wonders of Nature explained," "Humble Creatures" (a study of the earth-worm and the house-fly, in popularised language), "The Treasury of Knowledge," 
"Simple Lessons for Home Use," were the kind of cheaper works in touch with a past generation; these latter and other later well-intended publications will now be found to be somewhat deficient or even a little misleading entomologically; they abounded in pious sentimentality and mostly attempted an aggravatingly grandiose literary style, but all have rather failed in teaching practical economic utility, in connection with which nature-knowledge can be rendered as interesting as any other kind of instructive literature. The tribe of two-winged flies, in particular, has not even yet received a full and adequate study by scientists. A preference has ever been shown towards those other branches of entomology, which may be more interesting to the cabinet-specimen collector, but which cannot pretend to have an equal hygienic and economic importance to humanity.

The presence of the house-fly in our dwellings is often submitted to as an irritating but an inevitable nuisance; yet very certain remedial measures would almost exterminate the creature, which is a dangerous and filthy peril. To many people it will seem a most incredible exaggeration when told that it is really worse than any one of the less common creatures universally regarded with horror and disgust as pestiferous vermin. The surmise may be true that the disgusting body louse carried bacteria, which spread the "black death"; and, even though the rat's flea has been found to be the carrier transmitting bubonic plague, yet amongst people living now in civilised communities within the temperate zones these parasites cannot be ranked as dangerous equally with the house- 
fly. The modern crusade against the house-fly is not based on any such new discovery, as is that against the mosquito gnats, which are the means of spreading zymotic diseases mainly in the tropics. The malignity of the fly is recorded in most ancient history and folklore, yet not very long ago there prevailed amongst certain classes opinions very different to those of old as well as to those of the present day. A short anecdote will perhaps amuse as well as explain those misplaced sentiments, which have not quite died out.

In the middle of the last century there was a boy, thought to be too delicate to be sent to school, who early earned for himself the character of being a strange child. When barely more than nine years old he visited an Aunt who was a veritable exemplar of genteel breeding and propriety after the early Victorian pattern. There he was seriously reprimanded for the "cruelty" of feeding his secret pets, which were garden spiders, with flies which were, so the Aunt said, "poor innocent creatures made by God for a useful purpose," but, she inconsequentially added,- "Spiders were horrid." The strange child replied that the Devil made the flies, and that God made the spiders to eat them. The astonished Aunt then elicited the fact that the strange child's father had explained, during a Sunday Bible lesson, that Beelzebub (the Devil) meant Lordof-flies.

This strange child was taken a walk over Doncaster Heath by the Aunt's maid. There a dead rabbit was seen from which maggots were crawling, and the maid explained that it was fly-blown. Next they both stroked and patted a patient donkey, and the strange child 
observed maggots rolling out of the donkey's nostril * on to the ground; he wondered much that live animals should be fly-blown. He also saw with pity some cows, around whose eyes flies clustered.

Pondering on these matters, one day he confided to the Aunt his confirmed opinion in these words-"It seems, Aunt, to me that people who won't kill flies deserve to be fly-blown." Doubtless, it would have been better if he had expressed himself thus-People who will not kill fleas deserve to be flea-bitten; and people who will not wage war against flies deserve to be fly-tormented. However, the horrified Aunt mistook the observation for insult and impudent rebellion, and what ensued need not be related as pointing no useful moral. The strange child was merely a genuine early nature student ahead of the times by some fifty or sixty years. In due course he learnt a more orthodox account of "Creation," and the existence of mysteries in facts physiological and spiritual, which can only be imperfectly comprehended in this world.

His craving for nature study was not satisfied with the reading of most of the cheap books then published for the diffusion of knowledge. Collecting butterflies and moths sufficed for some of his schoolfellows in later years, but, not then having access to really good handbooks, he became an original investigator in wide ficlds of nature study, and thus learnt that many state-

"Stevens' Book of the Farm and many other publications describe the similar affliction of sheep by CEstrus ovis but omit to notice the case of the donkey, which I have witnessed several times, but have never seen a horse or pony thus afflicted. There is a fly termed (V)strus nasulis, of which the victimised host is uncertain, for Linnæus was mistaken in stating that the larvæ are found in the fances of "horses, asses, mules, stags, and goats," cutcrins by the nostril. 
ments and opinions, which ordinarily even at the present day pass current as facts, are erroneous and misleading. Accordingly, the reader need not be surprised at some statements in the following pages at variance with what may be met with elsewhere.

The old fanciful dogma that everything existing was actually created "in the beginning," and "for a purpose," was once ardently championed as controverting aggressive Voltairean ratheism, but it must be now recognised as an unwarranted assumption, deduced from an orthodox doctrine of "design," which in itself seems acceptably agreeable with the idea of unity, consistency, and perfection in Creation and The Creator. In fact the said "fanciful" dogma never really was an integral part of Christian Catholic doctrine. The house-fly, as we know it, is absolutely the developed product of human insanitation; scientifically and practically it is a new "species" of an old "genus" established by a long course of breeding in man-made environments. 


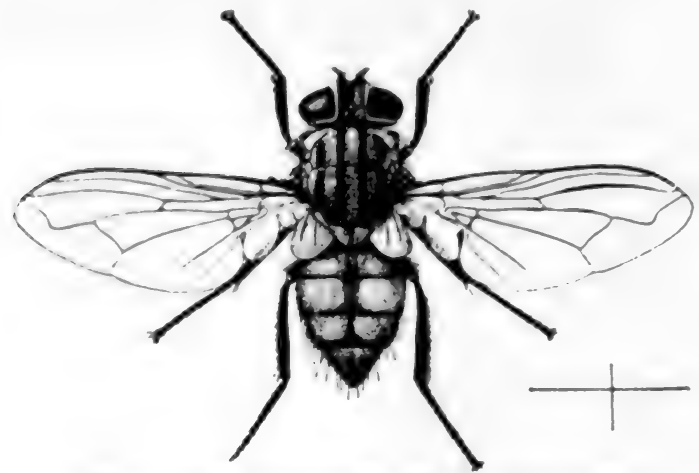

Fig. I. The House-Fly, Female, Eularged.

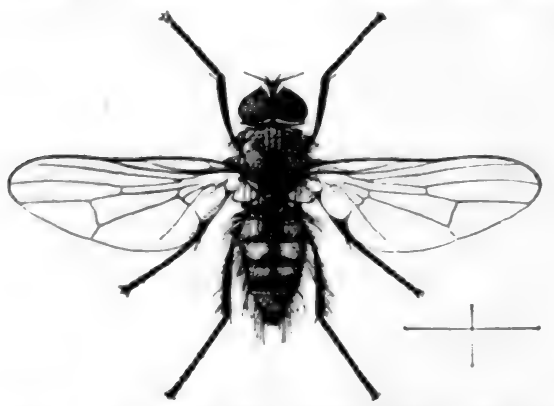

Fig. 2. The Lesser House-Fly, Male, Enlargat.

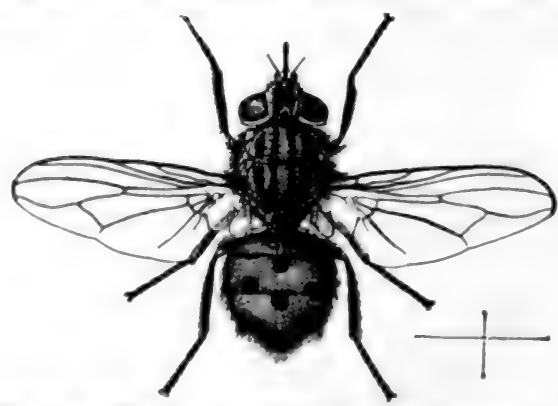

Fig. 2a. The Stable-Fly, Female, Enlarsist. 


\section{CHAPTER II}

THE IDENTIFICATION OF THE COMMON HOUSE-FLY

Although there are several other kinds of flies which occasionally visit the dwellings of mankind, there is one super-abundant species, Musca domestica, to which the name of "house-fly" pre-eminently belongs. In the scientist's discriminating judgment, when viewed microscopically, it differs substantially from others; but it differs very little in general appearance from certain outdoor flies and from one not uncommon indoor smaller companion, Fannia canicularis, which is not classified amongst the Muscide but amongst the Anthomyida. This latter has been fitly termed the "lesser House-fly;" it has the same habit of delighting to pester man as much as or more than cattle outdoors. Both these flies join with several others in frequenting stables and cow-sheds.

These two flies and the familiar "blue-bottle" (again it seems that we are liable to confuse two species) are the special subject of our present study; but it will be as well to take passing notice of some few other members of the tribe classified by scientists as belonging to the order Diptera. The species of this order native to Great Britain are said to number nearly three thousand, of which quite two hundred of largish sizes are exceedingly common and widely distributed. 
This order is characterised by the fact that all the species are furnished with one pair of wings only:dis $=$ double, pteron $=$ wing ; they all undergo a metamorphosis analogous to that of four-winged insects.

The dipterid flies are apt to be popularly recognised as flies (with fat bodies) and gnats (with slim bodies); but they may be more intelligently classified (with a few anomalous exceptions) as flies ( $\boldsymbol{a}$ ) having a trunk-like mouth or proboscis (miscalled a tongue), terminating with bilobed suctorial lips, and as flies (b) having a bayonet-like trunk, or a sheaf-like tubular spike with skin-piercing lancets. No two-winged flies have stings; the tail of the female, which terminates with the ovipositor and is retractile in a telescopic manner, is very soft and quite unlike the sting of the ichneumon or the ovipositor of the "saw-fly," both of which possess two pairs of wings like bees and wasps, and therefore are classified with the insect race called Hymenoptera.

Omitting Aphides (green-flies, plant-lice, and the like) which are an "order" by themselves, and excluding gnats of slim form, mosquitoes, and midges, which are mainly crepuscular, nocturnal, or shade frequenting, we might try unscientifically to sub-divide the more conspicuously sunshine-loving and day-flying flies into:-(1) flower and honey seeking flies; (2) cattle pestering sweat-flies; (3) skin-piercing, blood-sucking flies; (4) insectivorous flies; (5) fungus flies; (6) carrion and filth flies; and to these must be added another small group (7) which comprises those of the wondrous family of the CEstrida, the most horrible though not the most injurious of the animal perse- 
cuting and torturing flies; this last group, strange to say, are absolutely destitute of any mouth and feed only in the maggot stage. In many cases, however, it happens "that the males and the females differ in feeding habits as well as in colours and markings, whilst only their patterns of wing-veins and some less prominently apparent features are constant in the two sexes. These circumstances discountenance the above grouping.

Again, if we tried to group our flies with adequate regard to their very diverse habits of life, in the larval stage as well as to their subsequent metamorphoses, we should find that these are details which are obscure and in many cases unknown or imperfectly recorded. However, after much study and many revisions, a scientific classification has been contrived based upon the minutely differentiated characteristics which are technically explained in the Appendix to this booklet.

Whilst the notorious house-frequenting flies abovementioned and the blue-bottle are remarkably omnivorous in their feeding, the great majority of outdoor flies are quite otherwise inclined, and do not find much attraction in anything but their own individual preferences. Indeed, the breeze-flies, and many others, avoid human habitations; even the grey blow-fly, unlike the blue-bottle, rather seems shy of the house. In the above grouping, according to feeding habits, the housefly must be preferably consorted with (2) sweat-flies, but the blue-bottle with (6) carrion flies; however, the house-fly and the blue-bottle are very near akin, and by reason of similarity of wing-pattern both are included in the family of the Muscida. 
In the entomological systematist's classification the primary separation of flies into two sub-divisions starts with a difficulty, for it is based upon circumstances often obscure and in some cases at least imperfectly known.

The first sub-division, Diptera Orthorrhapha, comprises those flies which in the stage of the pupa or chrysalid disclose the outline of the perfect insect; in the other sub-division, Diptera Cyclorrhapha, there are grouped together all those flies of which the larvæ make for themselves a puparium or barrel-like case out of their larval skin.

The first mentioned sub-division comprises all the gnats, midges, and most of the slender flies which are outside the scope of the present work, but it also includes a few kinds of more stoutly built flies, to which some allusion will be made in the following pages, as for example, the breeze-flies, Tabanida.

The second sub-division comprises many families, including the muscid-like flies, of which the house-fly is the type. The flies of this type are to be found in the families of Muscida, Anthomyida, Tachinida, and Cordylurida, comprising nearly 700 British species, of which many rather closely resemble one another when superficially observed.

The approved classification of flies is to some extent dependent upon the formation of the antennæ, but the unique feature of the systematic differentiation is based upon a very intricate method of scrutinising, identifying, and numbering the vein-like strengthening ribs called veins, nervures, or nerve-lines, which, starting from the shoulder, mark with characteristic patterns 
the transparent tissue of the wing. We are rather compelled to follow something like this plan (simplified) for the purpose of clearly distinguishing the "lesser house-fly" from the common "house-fly."

In the accompanying illustrations rather similar patterns of wings are shown; these are typical of the Muscida and Anthomyida, which, taken together, comprise amongst others all the cattle and human pestering "sweat-flies"; only a few really blood-sucking flies are included amongst the Muscida.

In critically comparing these four patterns, the chief feature to be observed is the small rib-like nervure called the " discal " "cross-vein," which is situate in the very middle of the wing, and which connects the lowest of a group of longitudinal nerve-lines or veins in the front (or upper) half of the wing to the uppermost of the other group of longitudinal nerve-lines in the hind (or lower) half of the wing. Three "main" longitudinal lines, technically termed "veins," are theoretically recognised as constituting the upper group and four "main" longitudinal lines the lower group; but these "veins" (numbered 1, 2, 3, 4, 5, 6 and 7) will be found to be varied in different families and genera, each often with characteristic diverging branches, whilst some veins may be rather inconspicuous or quite absent. We will here devote our attention only to two such "veins," those respectively termed "vein 3 " and "vein 4 ," which are connected in the very middle of the wing, as above mentioned, by the small but always distinct " discal" "cross-vein." The illustrated patterns herewith show wings divided into about twelve compartments or cells, to all of which learned entomo- 
logical writers give troublesome technical names, not nearly so intelligible as the nomenclature symbols of the late Rev. W. J. Wingate, explained in the Appendix herewith. For present purposes a simple observation of the (externomedial) vein " $v, 4$," where it is the lower boundary of the (subapical) cell "O, $4^{2}$," will suffice.

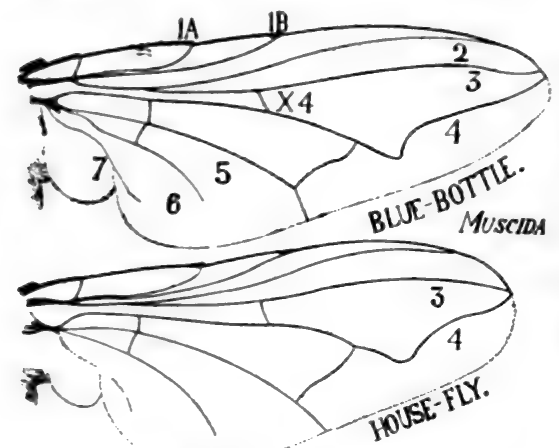

The pattern of the first figure illustrates the wing of the common bluebottle; here "vein 4" does not run at all straight in the last part of itscourse, but curiously bends very suddenly upwards at an angle and
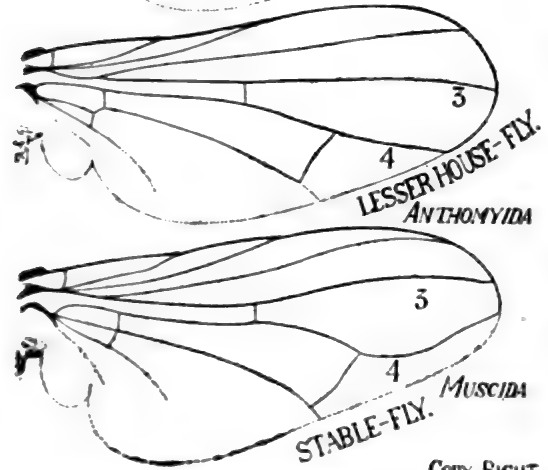
meets the margin very near to "vein 3." In the wing of a large blue-bottle it will be easy to recognise this plan.

The pattern of the second figure is rather similar, for the vein 4 likewise

Corr-Right has a sudden bend

Fig. 3. Wing patterns contrasted. upwards ; it terminates practically contiguous with vein 3 at the margin. This pattern is characteristic of the "house- 
fly"; thus it will be easy for the reader to identify the common house-fly by the close resemblance of its wing pattern to that of the blue-bottle, with which it is classified in the family of the Muscida.

In the pattern of the next figure the vein 4 runs comparatively straight throughout and meets the margin at a spot intermediate between the third and fifth veins; here all the main nerve-lines diverge more evenly and terminate more equi-distantly apart ; this latter plan is the wing pattern which will suffice to identify the lesser house-fly, but it is shared with all the Anthomyida, and more or less with some others, which are very common outdoor flies.

The pattern of the lowest figure illustrates the wing of the common blood-sucking stable-fly, Stomoxys calcitrans, which only occasionally invades the house. Here the vein 4 is deflected upwards towards the margin ending near the termination of the vein 3 , but the bend is a smoothly rounded curve and not a curiously abrupt angle, as in the first and second figures.

If the reader will study the house-fly in captured specimens, he will be able to observe that they slightly differ in their inconspicuous colouration and markings.

The male of the lesser house-fly is sometimes more observable than the male of the commoner house-fly, by reason of his being a most indefatigable dancer with companions in mid air around any central ornament, and also by reason of his possessing pale patches, more or less yellowish grey, on the sides of the abdomen; but such markings are also in some degree observable in other male flies, being very conspicuously of a brighter yellow in the common small outdoor 
raven-fly, $M$. corvina. The back of the thorax of the house-fly is marked sometimes distinctly, sometimes indistinctly, with four dark lines on an ash-grey background; the lesser house-fly has three faintly darkish lines only. Quite a number of outdoor flies have similar markings, but these often look like closely adjacent or indistinct spots. The wing pattern is the readiest guide for distinguishing the lesser house-fly, both male and female. The males of the hairy (almost bristly) raven-fly also indulge in the dancing habit, but still more so do those of the latrine-fly, Fannia scalaris, which may be distinguished by its uniformiy ashy-grey abdomen.

These common co-inhabitants of our dwellings vary in size according to their nourishment when in the larval stage (maggots); after the perfect insect emerges from the puparium, it swells out and fattens, but does not grow in the real sense of the word. If rooo houseflies will weigh an ounce, then it may be calculated that I 600 average specimens of the other kind will likewise weigh an ounce.

In representing that the house-fly exceeds the lesser house-fly in numbers in the proportion of twenty or thirty to one, it must be borne in mind that the occurrence of the latter varies widely-casually according to the locality, and temporarily according to the time of the year, being more commonly observed when and where the other kind is scarce.

The lesser house-fly has summer broods at longer intervals than has the common house-fly. Towards the end of the summer its last brood hibernates in the puparium, and emerges as early as the end of March 
or early in April, whilst the common house-fly is not usually observable until a later date, although it is credited with more generally braving the dangers of attempting to hibernate in the imago stage. My attempts to test the capability of the house-fly by aiding October and November flies to hibernate invariably terminated in the creature's death long before springtime. However, it is very apparent that under the shelter and encouragement of warm winter environments in towns, amidst restaurants, bakeries, large hotels and certain factories, as well as and even more than in mews, adult flies of the latest autumn broods can, to some extent, survive mid-winter with very little or no prolonged hibernation. 


\section{CHAPTER III}

SOME OTHER FLIES AND THEIR DIVERSE HABITS

Just as the common "house-fly" and the "lesser house-fly" are often in error regarded as the same species with an insignificantly small difference of size, so the identity of each in turn may be confused with several other species which are not uncommon, but they are all normally outdoor flies.

The chief of these is the excessively common stablefly, Stomoxys calcitrans, whose generic and specific designations are well given, for they mean "sharpmouth," "kicking," the latter word denoting the action of the tormented horse ; it has a long, thin, stiff, skinpiercing, shining black trunk, furnished with two lancets. It is an eager blood sucker. In size and colour it rather resembles the house-fly, but anyone who is keen sighted will recognise it at once by its bayonet-like trunk, held projecting prominently in front of its head. It is much addicted to basking outdoors on sunny walls, but on the approach of darkness or of inclement weather it will occasionally seek shelter indoors. Its wing pattern rather resembles that of the common house-fly, as has been previously explained.

Round about dairy farms Hamatobia stimulans, a fly slightly smaller than the stable fly, with a striped 
thorax and a blood-sucking trunk, will often leave the cattle to assail humanity. A still smaller, somewhat hairy, muscid type of fly, Lyperosia irritans, is also a common aggressor of oxen throughout the summer.

Musca corvina, the raven-fly, is smaller than the house-fly; it has very distinct dark markings; the abdomen of the female is chequered, but that of the male has a black central stripe on a yellowish abdomen. It frequents gardens, parks, and meadows. It is much less prolific than the house-fly, with which it shares the sweat-fly pestering habit.

Cyrtoneura simplex is a little smaller and more common than the species last mentioned; its larvæ are bred in the dung of cows and other animals which it very severely pesters. However, many species of dung-bred flies do not in the least participate in the cattle-pestering habit.

The Anthomyida are a family of about 250 small and medium sized garden frequenting and country flies, mainly of flower and honey seeking habits. Nevertheless, some are dung-frequenting ; none are blood-sucking, but several are cattle-pestering sweat-flies, which, even more pertinaciously than the house-fly, will circle round one's head and repeatedly buzz against one's face. Of these, the small Hydrotoa irritans and $H y$. dentipes are amongst the worst offenders. A few of the Anthomyida are vegetarian garden pests; the larva of the cabbage-fly, the root-fly, the onion-fly and the celeryfly are, in some seasons, very destructive. The socalled "turnip-fly" is a small striped beetle of the same genus, Phillotreta, as the unstriped "flea-beetle" of the hop-fields. The larvæ of the majority of the 
species of the family of Anthomyida are, more or less, feeders on decadent vegetable matter, but some, like those of the genus Fannia, are preferentially feeders on dung. The female of the latrine fly, Fannia scalaris, so closely resembles the lesser house-fly that only the expert with a magnifying glass, after a careful examination, can tell which is which; the male differs from the male of the lesser house-fly by being without the yellowish patches on the abdomen.

There is a larger and less common muscid fly, with an ashy-grey body, but with reddish legs, named by entomologists Muscina stabulans, which not only in body colour, but also in the pestering habit, resembles the house-fly; its Latin specific name is rather objectionable as too suggestive of the common "stable-fly," which name belongs to Stomoxys calcitrans abovementioned; its larvæ have been found in cow-dung, but they can also flourish on vegetarian fare.

The common blue-bottle is now named Calliphora erythrocephala (red-head), and it can be recognised by its reddish face and black hairs for a beard, whilst the less common blue-bottle, named Calliphora vomitoria, may be said to have a reddish beard upon a black face; the latter has the blue colour more evenly distributed over the abdomen, whereon the former has dark markings.

Polietes lardaria is a fly sometimes mistaken for the blue-bottle; its specific name is rather too suggestive of resemblance in habit. It may be recognised by its having four black stripes on the thorax, by its large white squamæ, and its tesselated glaucous abdomen; its wing pattern classifies it as belonging to the 
Anthomyida, whilst the true blue-bottles belong to the Muscida, and the grey blow-flies to a section (Sarcophagina) of the Tachinida.

There are some other outdoor flies which are not very dissimilar to the common blue-bottle, but they are more soberly coloured, ranging from bluish black to speckled and tinted greys; some of these have a pattern on the shiny upper surface of the abdomen which is conspicuously and beautifully chequered. Closely akin to these latter is the large grey blow-fly, or flesh-fly, Sarcophaga carnaria; it is much referred to in entomological books as of marvellous fecundity. The female deposits not eggs in a few hundreds, but already hatched maggots to the number of many thousands. Amongst half-a-dozen rarer kinds of smaller grey blow-flies the females differ in their striped markings, but their respective males seem quite indistinguishable apart.

Notwithstanding the prodigious fecundity of the grey blow-fly, the credit of being a practically useful scavenger of carrion must be given only to the bluebottle, which is of a more robust habit, and which so promptly monopolises available matter that Sarcophaga carnaria and her congeners are sometimes, perforce, compelled to give their larvæ a mere vegetarian diet.

The yellow cow-dung fly, Scatophaga stercoraria, is inoffensive, and one of the commonest flies observable in the course of a country-side ramble. It and its congeners are distinct in habits and appearance from any of the other flies above-mentioned. In this species the male is larger than the rather more smooth and 
dull-coloured female. Its body is furry but slender; it has small eyes and head parts. In repose it holds its wings parallel close above the abdomen, more like the "breeze-flies," or true "gad-flies," than the ordinary muscid flies. Although its proboscis does not seem as formidable as that of more insectivorous flies, yet it may sometimes be observed pouncing upon some small fly, which it holds with its powerful legs. This fly does not appear to be very predaceously inclined; perhaps it is only "acting a part," like some other creatures, including the amorous male of the common frog, which, failing to secure a more natural and complacent "partner in the dance," will in springtime seize upon and very persistently cling to an astonished carp.

Amongst many flies with bodies favoured with a brilliant metallic sheen, several species of green-bottle flies (Lucilia) are notorious. Of these latter L. Casar is the most common, but L. Sericata is by far the worst in England, not uncommonly laying eggs upon sheep; many are of a brilliant golden green, but some vary towards a coppery green; all have red eyes and silvery faces. In summer-time these flies seize every opportunity of depositing their eggs upon any sores or skin wounds of animals; their larvæ normally feed on carrion and dung. The green-bottle, like the bluebottle flies, are fond of both sweets and filth, but they do not pester wholesome animals as do the sweat-flies.

Next to the Muscida the most often observed and easily recognisable as a distinct family of flies are the Syrphida, which include the "hover-flies," the droneflies (often mistaken for the male of the hive-bee), and 
a number of other very common flies of a generally similar full-bodied shape, in most of which colour stripes and bands more or less suggest a comparison with wasps. The numerous species native to Great Britain are widely distributed, and, excepting the rare and very hairy Merodon narcissi, of which the larvæ feed on liliaceous bulbs, none is injurious and some are beneficial. Nearly all the flies of this family frequent flowers. The habit of many to hover for hours about a favoured spot, as if for mere pleasure, is remarkable; but it is not generally recognised that some of these hover-flies (of the genus Syrphus) are hawking for winged aphides and other small insects, which they quickly suck dry and drop whilst still on the wing. Many of the flower-frequenting Syrphida are great devourers of pollen; all have strongly developed suctorial mouth parts.

The larvæ of the various syrphid flies differ greatly in appearance and habit; some are terrestrial; some aquatic; some semi-aquatic; some feed on decadent vegetation; some on sewage and filth, and some are insectivorous. Most useful to the horticulturist are those of the genus Syrphus, which feed on green-fly and other aphides. The most curious in shape are the "rat-tail" maggots of the common drone-fly, Eristalis tenax (also others of allied genera), which can extend their long tubular tails and breathe atmospheric air through the same whilst lying under water. The larvæ of the genus Volucella are found dwelling in the nests of bumble-bees and wasps; it is rather uncertain how far they are commensal, or parasitic, or devourers of dead matter. Some of the syrphid flies are single- 
brooded, but some at least are double or treble-brooded in the year; records are wanting about many, and which, if any other than the common drone-fly, are multi-brooded. Anyhow, none appears to breed in Great Britain as rapidly as do the house-fly, the bluebottle, and other muscid flies.

The larva of Conops flavipes are parasitic in the body of the adult bumble-bee, and they pupate therein.

The small family of the Stratiomyida contains a few fairly common species called soldier-flies; these are interesting as linking Orthorrhapha with Cyclorrhapha; their larvæ are some aquatic (the star-tailed maggots), others terrestrial, and some have hard shelllike skins; but they are not so curiously like a creeping marine limpet as are those belonging to the genus Microdon (of the Syrphida), which are rare and wonderful dwellers in ants' nests.

There is a curiously shaped race of parasitic flies which cling to the host like a louse, called Hippoboscida ; these have more than the usual provision of claws to their feet, both in the number (normally two) and size of the claws. The forest or spider-fly attaches itself to some part of the body out of reach of the horse's tongue. The ked, tick, or sheep louse-fly has a similat mode of life, and, after selecting its host, it becomes wingless. These flies, strange to say, nurse and nourish their larvæ within the oviduct, and, when one might think that they were laying their eggs, they are depositing pupæ or larvæ just ready to pupate. There are some species of the family of the louse-flies which infest birds.

The true gad-flies of the family of Tabanida were, 
and sometimes still are called "blinden breeze-flies," and sometimes dun-flies; by a very easy mistake the countryman's word "blinden" (blind) has got changed by authors in books to "blinding," which is nonsense, and misses a wonderful instance of old-folk knowledge; the females are amongst the most inveterate bloodsucking flies, but the males are mere idle loiterers in summer sunshine on flowers; the eggs are laid on herbage in moist situations; the maggots and pupæ of many of these species are said "to be found in the soil," and some, if not all the larvæ, are predaceous, attacking worms and underground larvæ of various insects. They are more or less midsummer flies and are single-brooded. There are several largeish species (of the genera Tabanus and Therioplectes) found in Great Britain, and they are diversely distributed, being respectively woodland, moorland, lowland, and highland inhabitants. The great ox-gad-fly is as large as a bumble-bee, though more long than broad in body, but the term gad-fly is often wrongly given to the worble-fly, which is really more bee-like, being furry and rounder in body. The genus Hematopota comprises three smaller sized extra vicious blood suckers, $H$. pluvialis, rather common, $H$. italica, very local, and $H$. crassicornis, darker in colour and with spotted and dark tinted wings. Several of the large gad-flies have dull-tinted wings. They have large, shallow, brightly shining and curiously banded compound eyes, but no "ocelli"; they all seem to be at least semiblind, and the females are rather sluggish, except between the hours of $11 \mathrm{a} . \mathrm{m}$. and $5 \mathrm{p} . \mathrm{m}$. in bright midsummer sunshine. The females hunt entirely by 
scent and are easily captured when attacking human beings; they alight on their victims with a stealthy silent approach. They appear unable to discriminate between clothing and bare skin as suitable spots for feeding. Amongst a band of mountaineering pedestrians, on a sunny day, it was observable that there would be a dozen or more "blinden breeze-flies" settling on the back of one, whilst the rest of the party were only favoured now and then by one or two apiece. It was apparently the smell of the "home-spun " coat which attracted; the colour of the garment did not seem to be the cause of the selection. Sunshine loving flies prefer white and pale colours. If a dog could speak, he would explain the smell of some "finished" cloth, but, for the sake of the fastidious, the secret is not here disclosed.

Very closely allied to the true breeze-flies in habit of life are the species of the genus Chrysops, of which two only are often met with in England, namely Ch. cocutiens and Ch. relicta; these flies are very keen blood suckers; they are smaller, slightly more slender and brighter coloured than the commoner Tabanide; it is characteristic of the genus Chrysops that the antennæ are quite twice the length of the remarkably short horns of the majority of common full-bodied flies; all the species possess beautiful golden glittering eyes (whence the name Chrysops), and their wings are spotted and tinted.

One of the most horribly disgusting but serious facts connected with flies is observable most conspicuously amongst the wondrous family of the Estrida. These pass the larval stage of life, not on, but inside the 
bodies of living animals ; and the perfect insect, strange to say, is absolutely destitute of a mouth opening. Much misrepresentation has been prevalent, based entirely upon surmise, connecting "myiasis" in mankind, which is various but very rare, with the common infliction of horses and horned cattle with Estrid maggots. Myiasis is the medical term given to all the various forms of animal infliction by internal parasitic maggots, and this subject is reserved for discussion in the next chapter.

The characteristics and natures of the very numerous tribes and families of other kinds of flies will be found summarised in the Appendix of this booklet. 


\section{CHAPTER IV}

\section{MYIASIS AND THE ESTRIDE}

The family of the Estrida is the most curious and horrific of all the different tribes of flies; it is very limited in species, of which five or six are prevalent throughout Great Britain. The worst of these could be almost exterminated with ease, but unfortunately mistaken ideas have prevailed, and graziers commonly believe that though the sheep's nostril fly is conspicuously harmful and dangerous, the horse's bot-fly and its congeners are negligible as regards the practical health of the host. The bot-fly and the worble-flies are all of a largish size, only the sheep's nostril fly and Estrus hamorrhoidalis, which latter infests the throat and rectum of the horse, are of a medium size.

It has been known from very ancient times that man himself was not exempt from some fly, which was imagined to resemble the horse's bot-fly, and it has been wrongly surmised that many different creatures and all ruminant animals were more or less subject to the attacks, each one of its own kind, of œstrid fly. It is undeniable that man is sometimes internally afflicted with dipterid larvæ, but it is most certain that the fly to be incriminated is not a congener of the horse's bot-fly. 
An old illustrated French encyclopædic work gives coloured pictures of the flies and larvæ of $E$ strus bovis (the worble-fly of the ox) and of Estrus equi (the botfly of the horse), but only the larvæ of a so-called Estrus hominis is figured. Recently, however, new attempts have been made to identify the species causing intestinal myiasis, of which the larvæ are observable from time to time in the course of postmortem examinations and during anatomical study. Of recent years it has been suggested that the lesser house-fly is addicted to such a manner of breeding; then later that another species of the same genus has been found to be the real culprit. However, the peculiar larvæ of these last-mentioned flies do not in the least resemble the fat round larvæ of the true botfly or of the worble-fly, which are correctly represented in the above-mentioned French work, nor the round and rather smooth maggots which were observed in Westminster Hospital nearly fifty years ago, and at other places from time to time both before and since, giving rise to much wonder and discussion, and also to very incredible tales.

Another more credible surmise attributes the offence of human intestinal myiasis to Muscina stabulans; if this be correct, the infliction would be probably due to the subject having eaten damaged and egg-laden plums or similar fruit, for $M$. stabulans is credited with being normally, though not exclusively, fruitarian or vegetarian.

If any one of the above suppositions be true, it does not exclude any other one, amongst many. explanatory surmises, from being possible. Judging from the re- 
markable attractiveness of the odour of humanity to the common house-fly, and from the fact of the maggots possessing well developed tenter-hooks on their heads (somewhat like those which the bot-fly maggots use for internal attachment), it is just as likely, nay more likely, that this species (as the writer stated for the information of the authorities of Westminster Hospital nearly fifty years ago) is more than any other capable of adopting such a life-cycle existence ; these maggots would mature after five or six days feeding and then emerge. If there were a veritable " Estrus hominis," however rare, the hairy and peculiar female would be conspicuously observable, a persistent hoverer about the person of her victim until she had attached eggs to his body, from which the maggots would not emerge until after nine months. Most of the tropical flies, which are said to similarly attack humanity, may be rather compared to the green-bottle flies which infest sheep, but the latest medical records and reports profess to identify ten or twelve species of very different genera as having myiasic capabilities.

The family of Estrida has been fitly divided into three sections, namely, the Gastrophilina (the larvæ living in the gullet, the stomach, or the intestines), the Hypodermince (worble-flies), and the Estrina (nasal or nostril flies); all the species are hairy or furry, and the gravid females fly slowly with loud buzzing, in a characteristic attitude peculiar by the bending downwards of abdomen and tail, with a much extruded ovipositor.

The sheep's nostril-fly, Estrus ovis, has a chequered abdomen and is less hairy than others; it is the type of 
the section to which the generic term Cephalomyia is given in some books; species of this section attack deer and other animals.

The section termed Hypodermina comprises the "worble" flies or " marble" flies. One may imagine that the latter name indicates in the mind of the cowherd the appearance of the round pustulent boils on the hide of the suffering animal, and that the former name is a corruption of "worm-hole," originating with the tanner, observant of the deterioration of injured hides. A mixing of the terms worm-hole and marble probably originated the name "warble." The maggots live under the skin on the back of oxen, and breathe externally through openings in the boil-like excrescences. The discoloured flesh of infected oxen is called "flecked." Two species of worble-flies are prevalent, one or the other, in many parts of England.

The third section, to which the sub-family termed Gastrophilina is sometimes applied, comprises the "bot-fly," which commonly infects the horse ; it is the imperfect knowledge of this latter which has led to erroneous surmises explanatory of the horribly disgusting fact of human intestinal myiasis.

All the species of all the three sections are singlebrooded. Although the flies themselves can inflict no immediate pain, at their mere sight all the animals out at grass on the farm are seized with an instinctive terror, conspicuously greater than when attacked and copiously bled by any "blinden" breeze flies, which, however, fly more silently and settle on their victims very furtively. One can understand the violent efforts of the horse to free himself from the exceedingly 
painful bites of a newly attached forest-fly, but one can only wonder at the frantic galloping of oxen and horses to and fro when a non-biting œstrid fly buzzes about like a harmless fat bumble bee and slowly approaches.

The females of all the worble-flies, the nostril-flies, and the bot-fly are short-lived, appearing on the wing in August, possibly seen a few days earlier. In the act of ovipositing they make themselves very conspicuous; they lay their eggs whilst hovering in the air, their extruded ovipositors attaching glutinous eggs to their victims. The hatching of the eggs of the bot-fly? is assisted by the habit of animals to lick themselves and each other, when certainly their warm, moist tongues will convey into their mouths the newly emerged bot-fly's maggots, which many months later are to be found attached to the internal lining of the unwilling host's stomach. When fully grown in June, these maggots loosen their hold, are discharged with the dung, and pupate in the soil.

No satisfactory account has yet been given as to the early stages of the maggots of the worble-flies. The eggs, having been attached to hairs on the host's hide in August, the prominent round pustulent swellings, called worbles, wherein the maggots dwell, do not become conspicuous until the following months of April and May. It is a reasonable surmise that the obscure and long first-period of the maggot's existence may more or less conform to that of some of those flies which are also single-brooded but are predaceous or parasitic on insects. The newly hatched maggot perhaps can crawl, but does not feed until after several 
moults; at each moulting the strange creature becomes smaller and smaller, but probably at the same time is provided with a new head well suited for the purpose of that period ; firstly, with a burrowing or grappling head, and in due time with a feeding suctorial mouth, and then only does practical growth begin. No dipterid flies, at all events, known to be native to Great Britain, possess skin-piercing ovipositors.

I have been astonished to read in current literature much about œstrid flies which is not in agreement with my long course of personal observation; for instance, one high authority (F.R.S.) writes that œstrid "flies" appear from May until October, and hints that their egg-laying aggressions upon their victims are not conspicuously observable. I feel confident that the facts are quite otherwise.

That the bot-flies normally (and a few others abnormally, but for short periods only) pass a very long larval stage in the stomach and alimentary canal of herbivorous animals is one of the greatest marvels of insect life. All other growing creatures, which normally breathe in free air, require a certain large amount of breathable oxygen; and they would be stupefied or killed by a much smaller percentage of carbonic dioxide and other fermentive gases of digestion than undoubtedly exist in the strange abode wherein the bot-fly maggots dwell during the entire period of their feeding career. It has been stated that fly maggots artificially ingested into the human system have emerged alive in a normal condition, but the repulsive and objectionable experiment is not stated to have procured well nourished and full grown nor- 
mally pupating larvæ. Some of the maggots of human intestinal myiasis are not perhaps amenable to artificial culture up to the stage of final metamorphosis; and they do not appear to have developed a breed or new species with a distinct habit of life. All the credible accounts of human intestinal myiasis point towards some fly which is plural-brooded, and of which the larvæ develop rapidly and promptly quit the body all at once; otherwise more than one infection must have occurred. The tales of prolonged continuous breeding, with slow and prodigiously copious emergings at intervals, should be altogether discredited.

It is an amply warranted criticism to say that recently published records by authorities, in an endeavour to comprise every reported instance of myiasic infection, seem to countenance mere coarse Gargantuan jokes. On the other hand, it is painful to read such a "cockand-bull" story as that of the doctor about his elderly lady patient, up whose nostril a gravid female bluebottle flew and successfully performed the prolonged and delicate operation of laying therein a large batch of eggs, in spite of all attempts to expel the invader by violent sneezing. Day by day the said doctor observed the terrible injury, and the symptoms accompanying the growth of the feeding maggots, whilst the injection of a spoonful of paraffin would have effected an instantaneous cure. 


\section{CHAPTER V}

\section{GENERAL LIFE HISTORY}

Whereas the blue-bottle rarely enters the dwellings of mankind, except gravid females led by the sense of smell in search of fish, or flesh meat, and (less eagerly) sweets, both species of house-fly and both sexes seem to delight in the mere odour of humanity; breeding females will seek the larder and the dust-bin, but others will very provokingly pervade all quarters. Although avoiding a dark or deeply shaded room, the house-fly seems to like partial shade; it will be content to remain indoors and to rejoice in a warm kitchen, even on a hot summer's day, whilst all the other kinds of flies are enjoying the outdoor sunshine. It may be said of nearly a dozen other species, occasionally observable crawling on window panes, that they are "outdoor" flies, and that their occurrence indoors is accidental. In fact, they are mostly observed when trying to escape.

Next after human habitations, stables, cow-sheds and pig-sties are the delight of the breeding female housefly. Round about and in these latter resorts she associates with an immense host of rather small sized flies, and amongst a few others of equal size with the skin-piercing and blood-sucking stable-fly; but many stablemen are ignorant of the difference of the two 
kinds of flies and of the serious suffering of their horses from the bites of the stable-fly. This lamentable ignorance was shared by the joint authors of "Humble Creatures," published in 1858, when Neo-Darwinism was in vogue, and many books were published for popularising a knowledge of common things and spreading an interest in nature-study ; this publication, which is still (1914) in print and very little revised, has probably led some later would-be nature-study teachers to follow suit in confusing the characteristics of the two species. Very often the fly most numerously breeding in the manure heaps of the mews will be Borborus equinus, or some other of the same family, which are characterised by a very simple pattern of wing nervures and by the absence of squamæ or scales behind the wings; also the ankle joints of the feet are most peculiarly short and broad. B. equinus, and a great host of other dung breeding flies of a still smaller size, may be considered beneficial insects; they do not pester cattle, and their larvæ make food more scarce for injurious flies.

The breeding habits of the blue-bottle are very conspicuous by reason of its haste and boldness in taking possession of dead animals. It is incapable of breeding in horse or cow dung, to which latter the greenbottle fly often resorts.

The blue-bottle deposits her eggs, 500 or 600 , preferably on dead fish, or flesh, and sometimes on the sores or the flesh of wounded animals, but both the house-flies preferably affect dung, carrion, garbage, and all kinds of fermenting vegetable matter. It has been commonly but not truly said that the principal breed- 
ing places of the house-fly are the mews and the farmyards where manure is allowed to accumulate; the house-fly has a preference for horse dung before cow dung, which is preferred by some other kinds of flies ; however, near towns, the domestic dust-bins, heaps of market garbage, and deposits of town refuse give rise to a worse plague of house-flies than stables. All these flies deposit batches of white eggs, and are careful to place them as much as possible in crevices and shielded from exposure to strong light, or from draughts.

The two house-flies and the blue-bottle have similar larval stages, but their larvæ, called maggots, differ. The larvæ avoid daylight and cannot withstand dryness. As the larvæ feed, they have the power of ejecting or excreting a juice, which dissolves the food before they imbibe the material; their mouths are suctorial and are destitute of teeth or biting jaws.

The larva of the house-fly is an eyeless and legless maggot, one half inch long when full grown and extended; twelve cylindrical segments may be counted in its body, or even thirteen if we separately distinguish the small head segment, which may be withdrawn, and but little observable; five or six rear segments are of nearly equal stoutness when only half grown; afterwards counting from the three stoutish rear segments, the others taper towards the very small head. The middle and rear segments have pad-like bristly processes underneath, which aid the maggots in creeping, in which action they also make much use of the head segment's grappling hook. The maggots feed voraciously, but they seem, like the larvæ of the 
honey bee, to pass out very little anal excreta ; some have thought that, like what is said of bee larvæ, no excrement is discharged until after the imago has emerged from the puparium ; but such conduct seems altogether incredible. In the bee-hive doubtless the assiduous workers ever wash their babies clean and lick up all matter, just like domestic cats and dogs, when nursing their young.

The larva of the blue-bottle, called a gentle, is proportionately larger but very similar, except that the rear segment possesses a ring of tubercles, which may have some useful function in connection with two breathing tracks, which have their orifices at that part of the body.

The larva of the lesser house-fly is very peculiar; all its segments have projectıng tubercles; its whole body is rather louse-shaped, having not cylindrical but somewhat flattened segments, of which the middle are the broader, and those near the head and tail the narrower.

The transformations in the case of the blue-bottle are typical of the house-fly and others of closely related families and genera which are many-brooded within the year ; these creatures develop very rapidly immediately after emerging from the egg. Some other kinds of dipterid maggots, which are single-brooded, pass a very prolonged and obscure early period of skinshedding and non-feeding, a preparatory sort of babyhood metamorphosis; then at last they begin to feed voraciously and to follow the general habits of other maggots. Some maggots curiously refuse to feed except in company; probably some are unable to feed 
on dung except where other species are providing the necessary dissolving juice.

When the common maggots or gentles have ceased feeding, they burrow into the ground or crawl away, often to a considerable distance, apparently seeking a secluded, a more wholesomely clean, and a dryer spot. During this migrating time, they are palatable food for many birds, which would not eat them in their former food-loaded or unscoured state. Indeed, it is doubtful whether either a vulture or a raven could eat a fly-blown carcase without danger of myiasic punishment. The skin of the larva whilst growing is transparent, but, when about to pupate, it thickens and becomes an opaque creamy white.

The most marvellous part of the metamorphosis of the blue-bottle is concealed, when the gentle becomes the pupa; according to Réaumur the embryonic fly develops most curiously inside the puparium by a procedure not exactly like the change from the caterpillar to the chrysalid in the case of the butterfly. After a pause of a day or two, the front segments of the fully fed maggot contract, so that the body assumes a barrel-like shape; the skin then hardens, and turning a reddish brown it becomes a much contracted shell or case called the puparium. However, the long slender maggot has done something more than merely shrink and shape itself conformably to the case; it has withdrawn its embryonic head, so small as to be hardly distinguishable microscopically, together with its embryonic legs, wings and thorax into its embryonic abdomen! As the development proceeds, and the embryonic members of the future perfect insect acquire 
their destined shape, the immensely increased head and the thorax with its appendage members slowly emerge, and the partly inverted integument of the abdomen rolls back, disclosing the shape of a fly not before recognisable.

Other naturalists would have it believed that the true account of the transformation is as follows,- - when the maggot has shrunk and freed its body inside its skin which forms the case or puparium, all its preexisting internal organs become absolutely dissolved; then out of the fluid mass a new growth ensues, constituting the pupa with its recognised shape. This account is the one represented in most modern entomological books, and is based partly upon B. T. Lowne's monographic work on the blow-fly.

The comparative embryologist of our day is inclined to be a hyper-theorist, and so it seems that some have not remained content with either of the above accounts ; to them, apparently, the production of the large and complex head of the imago out of a single small anterior segment of the maggot requires a more recondite explanation, and must be brought into harmony with analogous facts. To this end some degree of linked support is found by the investigations of microscopic anatomy, and it has been conjectured that not one or two head segments, but five are lying blended and embryonically hidden in the larvæ, all ready to bud forth. However, for fear of wearying too much with the theories of advanced erudite scientists, the following jeu d'esprit is presented, instead of a more elaborate and sober attempt, to lure the unscientific lay reader to an extreme hypothetical conception of 
the "essential unity" underlying the apparent diversities of Nature within that vast domain of the Kingdom of Fauna, which is obviously outside the later creation of a vertebrate Animalia.

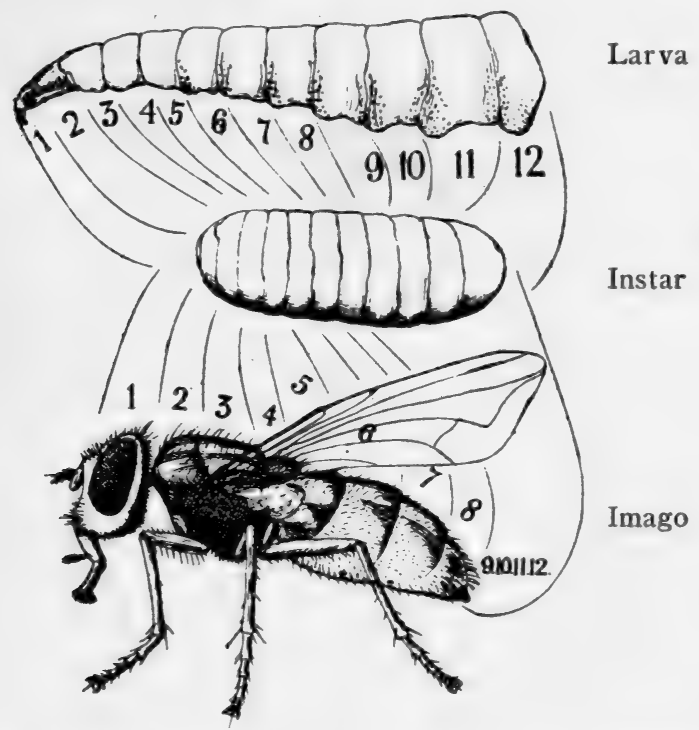

Fig. 5. Illustrating the debatable continuity of a I2-segmented structure throughout the metamorphosis.

The futurist's dogmatic CREDO of creative progress, "For him who would meritoriously pass his histo"logical examinations, and qualify as a Professor and "Doctor of Science, above all it is necessary that he "should acknowledge the unicellularity of the primæ"val OVUM (or egg), whence proceeds the seventeen"segmented boneless ANNELID (or worm), out of "which there develops the quadrangular articulated 
"crustacean INSTAR (or shell-encased aurelian), which "metamorphosises into the winged IMAGO (the an"gelic? or diabolic? fly); in the contemplation of this "knowledge alone is there supreme Darwinian Modern"ismal salvation and felicity." Amen.

In view of the prosaic illustration of transmutation, figure 5 above, the futurist disciple will have to accept the seventeenness of segmentation by something like faith without sight.

The quadrangularity of the crustacean stage is based upon the idea that the wings bud out from the two upper corners, whilst the legs develop from the lower corners of the transmuting instar.

Perchance the reader will desire information about the use of this curious word "instar," which has not the honour of notice in Dr. Sir J. Murray's New English Dictionary. One might well feel proud of the opportunity of adding the smallest item to such a stupendous and monumental work, but I fear I am only qualified to venture a fair guess. Virgil, I believe, used this term in allusion to the legendary wooden horse of the Greeks at their siege of Troy. Some time less than one hundred years ago entomologists recognised that the words aurelian, chrysalis, and pupa were none of them an inherently fit term of general application to the stage of insect life to be indicated. After many attempts, this latest proposed substitute seems to be gaining favour.

The fly emerges after bursting apart the first four segments of the puparium; this it does by a curious provision, whereby it can inflate a chamber in its head in a queer, balloon-like fashion, making a bag-like 
extrusion, which it uses as a punching and pushing machine.

After emerging from the ground, the fly withdraws the bag-like extrusion and cleans itself. Its body soon grows fit and it becomes very active, as long as daylight and warm weather favour it; otherwise it seeks shelter and becomes quiescent; however, artificial light and heat will awaken it to nocturnal activity. Sweets, carrion, and filth are all attractive to the bluebottle, but the house-fly and the lesser house-fly also find extraordinary attraction in both man and his dwelling.

Considering the superfluity of other flies, and the multitude of other insects ever ready to do duty as devourers of carrion, garbage, and filth, the scavenging services of the larva of the house-fly can be well dispensed with.

In civilised communities cremation in a refuse destructor is the only'sanatory method of treating town refuse. The economic value of the fly is very little, and consists merely in its food value for certain birds.

In warm weather the scavenging capabilities of all the carrion and filth feeding maggots are very remarkable, and there appears no exaggeration in the statement by Linnæus, that the progeny of three flesh flies can eat up the carcase of a horse sooner than it could be devoured by a lion.

When a batch of eggs has matured in the abdomen of the female, she is most careful in the location and manner of their disposal. Guided by the sense of smell, she will not lay her eggs except in contact with food, or in places securing her progeny access to their 
intended food. By the use of her soft, slender ovipositor, which is telescopically extensile and flexible, the eggs are deposited in shaded and concealed situations.

The house-fly is credited with laying batches of eggs at intervals, perhaps four or more times, and about $\mathbf{1 5 0}$ on the first occasion, then 100 , and less on subsequent occasions. Under favourable circumstances the eggs may hatch within a few hours of their being laid. The maggots of midsummer broods may be full grown and pupate in six days, and the perfect insect may emerge from the puparium in another ten days of warm weather, but in cold weather the pupæ of autumnal broods may remain dormant for several weeks, or even months. When nine or ten days old the mature fly may begin to lay eggs; hence, with such a life-cycle, in a month of very favourable weather the progeny of a single pair may number, say, 500 ; in two months' time the number may become 250 times 500 ; and in three months' time many millions! 


\section{CHAPTER VI}

\section{THE STRUCTURE OF THE HOUSE-FLY}

The house-fly has quite the typical insect form, inasmuch as there are three well defined sections of body - the head, the chest or thorax, and the abdomen; also it has three pairs of legs, each with nine joints, of which five joints constitute what may be called the foot. The twelve segments of the maggot are observable as twelve rings in the puparium, but in the fly the three which form the thorax look like one, whilst the eight which should theoretically exist in the abdomen look like four or five, until the rings of the ovipositor are counted.

The illustration on page 39 will make plain how the permanence of the twelve-segment structure (conspicuous in the larval stage) has been thought to persist throughout the life-cycle, but at the same time will disclose how great is the change in the relative proportions of these segments.

The prominent features of the hemispherical head are the two large compound eyes and the proboscis or trunk-like mouth. The antennæ or horns are very short appendages with three joints; small plume-like projections, called arista, are attached to the third segment; the horns hang down over a hollow in the middle of the face, and are insignificant in size when 
compared with those of other kinds of insects; but their structure viewed under the microscope is intricate, and they may be efficient organs of sense perception, probably in part auditory. The really unique feature is the retractile and suctorial proboscis, which is often incorrectly regarded as the tongue ; it is normally held doubled up and withdrawn towards a hollow under the head, whence it is from time to time extruded. The structure of this member is characteristic of the entire tribe to which the house-fly belongs; it is a fusion or combination of mouth parts, which in other insects are used more or less separately for the various functions of inspecting, biting, masticating, drinking and swallowing. In the house-fly the proboscis is absolutely suctorial, and is not provided with the lancets used by the blood-sucking flies for piercing the skin. Two maxillary palpi are attached to the upper or basal part of the proboscis, which is called the rostrum (a snout); the lower part is called the haustellum (a pump), and it has at the end a pair of soft cushion-like lobes or lips, which, when spread apart, form a heartshaped pad with an opening in the centre. The maxillary palpi are used for feeling and probably smelling. Each mouth-lobe has a main collecting central channel and thirty subsidiary cross channels of a wonderfully complex character. Imbibed fluids pass from the mouth-lobes to the gullet along a passage in the haustellum and the rostrum.

As with many other flies and other insects, there are on the top of the head very small simple and rather inconspicuous eyes called ocelli, three in number, between the large and prominent compound eyes, 
which latter are said to possess each four thousand facets. The compound eyes of the male fly are proportionately larger than those of the female; it is quite observable that they approach each other more closely at the top of the head, a feature of sex differentiation which is shared with bees, wasps, and many other insect creatures. It is thought that a single brain image arises from the combined views of the four thousand facets of the compound eyes blending with the view conveyed through the "ocelli." However, it is a most curious fact that it is the inconspicuous ocelli which are of supreme importance visually. The compound eyes have doubtless some special function, but throughout the insect world the size of compound eyes is not a certain indication of keenness of sight. The vision of the fly is good for distinguishing the movement of any broad mass, but it is rather ineffective for observing a thin line, as may be proved by slowly lowering a knife blade, with a steady hand, when its body may be severed before the fly takes alarm. It is a remarkable fact that the family of Tabanida (blood-sucking breeze flies), which are destitute of "ocelli," are the dullest sighted of all flies; in fact, at least semi-blind. Moses Harris observed that a blue-bottle became practically blindfolded when its ocelli were covered with an opaque pigment. Probably this is the case with other insects. Bees, which require long distancel sight for home returning, are well provided with ocelli. Butterflies, however, without the use of ocelli have a distinct faculty of daylight vision for a moderate distance. The investigation of sight by blindfolding is very difficult in flies. 
There are two cephalic ganglions, which are regarded as the brain; these are situated in the upper part of the head close to the neck. There are also ganglions in the thorax with connections extending into the abdomen.

The thorax is mainly occupied with the powerful muscles which actuate the attached wings, the legs, and the small appendages called halteres or balancers, which are supposed to be obsolete hind wings. There are three unequal segments in the thorax; the pair of front legs belong to the first segment, the wings and the pair of middle legs are attached to the second larger segment, whilst the third is connected with the hind legs and the halteres.

The breathing apparatus of the fly is distributed in portions over the head, thorax, and abdomen ; it consists of a number of internal air-sacks with membranous ducts ramifying everywhere; the largest air-sacks are in the abdomen near the waist. There is a pair of external spiracles to each segment of the body, and these lead to the air-sacks.

The lines on the wings of the house-fly called nervures have already been alluded to in Chapter II. These nervures are strengthening ribs to the transparent tissucs of the wings. The tissues are double (top and bottom) enclosing the nervures, which are so united to the connections called trachæ of the air-sacks, that the newly emerged fly helps to extend its limp and crumpled wings by a process of inflating the nervures.

The stomach is located partly in the thorax and partly in the abdomen. A passage from the gullet passes through the neck into the lower part of the 
thorax, where are the entrances to two long capacious chambers, of which the upper one is the true stomach and the lower one a store pouch, which latter may be likened to the honey bag of the bee. The fly habitually regurgitates liquid food stored in this pouch, and, somewhat after the manner of the cow chewing the cud, passes the same back into the true stomach, whence it proceeds onwards through the digestive track.

The abdomen holds all the other ordinary internal organs including that which may be called the heart, and which lies above the stomach; it consists of a long muscular tubular vessel with four contractile chambers.

Although the organ called the brain is located in the head, and although that called the heart is in the abdomen, yet some sense of control over bodily motions curiously exists separately in the ganglions of different parts of the body. This fact seems to make it possible for one extremity of the body to continue performing a pleasurable action (say, the head drinking honey) after the other extremity has endured a painful catastrophe (say, amputation of the abdomen). However, it may be fairly surmised that no creatures of a lower grade than warm-blooded vertebrate animals feel pleasure and pain in any way at least after the manner of mankind.

The most vital part of the fly is not the head but the thorax. A severe squeeze on the thorax will effectually paralyse and kill the creature. Muscular movements of different parts of the fly's body, which continue after severance or other fatal injury, cannot be regarded as visible proof of a slow death and prolonged sensibility.

Possessed of six legs, each with nine joints, the fly 
exercises a unique capability of walking; the legs are moved three at a time, a front and a hind leg on one side advancing simultaneously with the middle leg on the other side; thus the fly proceeds most securely always poised on three feet, which are so well furnished with pads, claw-like hooks, and hairs, that it can walk over polished glass and can even walk upside-down along comparatively smooth surfaces.

In comparison with the more heavily constructed wasp, with its four wings, the house-fly, with its two wings, is the more alert and active flier. The wasp is more robust than the fly and will be active in weather too inclement for the latter; however, some of the frail and slender gnats will brave cold temperatures impossible for the wasp. 


\section{CHAPTER VII}

\section{DISTRIBUTION AND CONCENTRATION OF FLIES}

It might be supposed that a strongly developed house haunting proclivity would not be consistent with a disposition to roam far afield from the locality of birth. Many clever experiments have been made with marked flies released and recaptured within measured distances and times. After an immensity of pains taken, very little profitable knowledge has been arrived at thereby. Little of what we really want to know is indicated by such a fact as that, out of hundreds or of thousands of marked flies released, one per cent was recaptured at spots as remote as a mile within two or three days, or by such a fact as that a large percentage should be observed to remain within a more limited home circuit. The variable factors of temperature, wind, sunshine and rain inevitably tend to discredit the reliability of the observed results following any such experiments.

Close observations of the habits of the house-fly reveal the very appurtenant fact that the movements of newly-hatched flies, for their first six or seven days' active life, differ from those of a more mature age, when the breeding instinct has grown strong. The latter are disposed to locate themselves for the rest of theit lives in and about one attractive spot, and they are indisposed to fly high above ground or to travel far, 
unless it be with the object of leaving an unsatisfying locality and discovering a better place. However, the younger flies seem to feel no such restrictive influence, for, as soon as they have become fit and the weather suits, they show an inclination to fly high and thus may travel to very remote places. It is just the same with peacock, red admiral, and tortoise-shell butterflies, which I have often reared and released for adding to the interest and beauty of a flower garden. In sunny weather many or most will soon wander never to return; those which have remained a few days continue residence close round about, especially if nettles, the food plant, grow in the neighbourhood.

It would be of great interest if we could discover how far a plague of flies arising from unsanatory surroundings in one locality is liable to spread to the injury of other localities.

On this subject nothing useful can be said other than can be safely surmised from the known habits of the fly. The female has none of the attachment of the honey-bee to its hive and community; she is not moved by an instinct like that of the wandering bumblebee in spring to found a colony; she is indeed very solicitous about the disposal of her eggs, but she is not impelled by any desire to place successive deposits in one locality.

The lesser house-fly has proclivities similar to those of the common house-fly, but probably she travels less far afield although a little more inclined to outdoor life.

Very little is known about most of the common outdoor sweat-flies. Some breed in dung, and may be 
many-brooded and otherwise resemble the house-fly in prolific increase ; others are more consistently vegetarian in the larval stage and slower in development; and some are possibly even single-brooded, like certain foreign large sized flies which fortunately appear only for a few weeks of summer weather, for they have a curious semi-bloodsucking habit of feeding after or alongside the skin-piercing flies, and their suctorial mouths are capable of further inflaming wounds and carrying infection from one animal to another.

The robust blue-bottle very closely resembles the house-fly in an inclination to spread the brood. Mature females, however, do sometimes show a slight temporary kind of "homing" instinct; having secured a cosy corner and a well sheltered retreat in a sunny wall, the occupant will battle for its possession, buffeting new comers.

Some of the smaller filth flies and many of the fungus flies have their lives, in the imago stage, influenced and shortened by their extra early sexual maturity; the females are fertilised whilst newly hatched and their wings limp and unfolded. This fact accounts for our seldom seeing some kinds of these flies abroad except females; and these are never seen to indulge in dances, flirtations, and games of chasing and buffeting each other, after the manner of so many kinds of flies. They habitually fly low ; nevertheless they travel very great distances, for, though short, their flights are incessant when searching for their special kind of food.

The most disinclined to roam of all common flies is the stable-fly. None other is a more eager seeker of sunshine, but when basking on a sunny wall it seems 
unwary and sluggish ; it is seldom to be seen far from where horses or cattle are stationed or stabled; however, it will make very long journeys hovering about a driven horse or reposing on the car.

A plague of flies of local origin will not take many weeks of summer weather to spread, but it is generally observable that plagues of flies, like many other occurrences, are simultaneous co-incidences distributed over wide areas and at places remote from each other. 


\section{CHAPTER VIII}

\section{NATURAL ENEMIES AND PARASITES}

Flies, which are such insidious and pertinacious persecutors of man and beast, are themselves the prey of innumerable enemies; many species are much sought for by birds, they are devoured by lizards and toads, and they are equally preyed upon by predaceous insects. Those flies which have bodies with banded colours, and which otherwise somewhat resemble bees and wasps, probably escape being the victims of some birds; but the tribe of flies does not, like the beetles, the lepidopteræ, and some other insects, furnish instances of other common protective devices, such as bearing and voiding offensive secretions, or attempted concealment in repose by mimicry of environment.

All insectivorous birds are fond of a diet of flies, and we may largely attribute the spring-time immigration of the beautiful swallow tribe to the fact that in the northern parts of the temperate zone swarms of soft bodied dipterous insects abound, and there replace the hard cased and more chitonous insects of hotter countries. The true swallow, the house martin, and the sand martin, all require a special food for their nestlings; and they also then require the longer summer days and the prolonged twilight of our 
northern clime for the frequent feeding of their young. The prevalence of flies near houses partly accounts for the partiality of the swallow for nesting under the eaves of our dwellings, where unfortunately the aggressive, the pampered, and the demoralised sparrow in towns generally prevents successful breeding by appropriating its nest and sometimes by eating its eggs. People who desire to favour the breeding of the swallow should destroy the nests immediately after the migratory departure of the builders. Their retention until the following spring is in no way an enticement for rehabitation ; on the contrary, it favours the objectionable habit of the sparrow to use them for a night resort, whereby they become very foul with bird vermin. The cleanly swallow annually desires a newly built habitation, and a bare peg projecting two inches from the house-wall will much encourage swallows to start the foundations of a nest thereon.

Ground feeding birds of many kinds eagerly search for flies, their pupæ, and their larvæ; even some finches will add flies to their diet in the nesting season. Chaffinches are very fond of the house-fly at all times.

The wasps are assiduous hunters of flies, and, though possessing less agility than their prey, they manage to pounce upon many victims. Very common enemies are the predaceous Empida, of which numerous species are native to Great Britain. Less common, but very observable when met with, are the closely related robber-flies, Asilida, which are hardly ever to be seen on a hot midsummer day without a captured fly held between their strong front legs. The largest 
of the robber-flies, A.crabroniformis, is a conspicuously fine insect. It equals the hornet in length, but is more slender in body, tapering throughout the abdomen towards the tail; it resembles the queen hornet in colour. The dragon-flies also eat flies, but they mostly feed upon winged aphides, gnats, and the like small game.

More secret destroyers of the fly brood are a few rather obscure creatures akin in their nature to the ichneumon flies, which are parasitic mainly but not exclusively on lepidopterce. Likewise, certain insectivorous beetles share in the good work of $\mathrm{fly}$ destruction.

Flies are often observable encumbered with minute vermin; some of these are true lice, and some are allied parasites called false-scorpions or chelifers. These are acquired whilst frequenting dung and refuse heaps, where they abound; thus, probably cheesemites and the like are conveyed by flies into our larders and warehouses.

It is not only the web-weaving spiders which prey upon the proverbially "silly" flies; there are also roving spiders which do not contrive webs, and some of these are nocturnal feeders; the latter can only be seen in daylight by looking for them underneath stones and in other hiding places.

Other fly destroyers are internal parasites, and these include thread worms (Nematoidea), as well as Proto$\boldsymbol{z}$ oa of obscure kinds. These are being scientifically studied by experts, and their life-history is as curious as that of others of the same order, in that they pass from one host to another, which fact for long helped 
to baffle investigation. Some have now been proved capable and others are suspect of baneful possibilities.

The house-fly fungus, Empusa musca, which is prevalent in autumn, has ever attracted popular wonder and much scientific attention. It has been much written about and plentifully illustrated, but the complete life-cycle of this peculiar parasitic growth is not yet understood; much that has been published as of fact is mere "copy" repeated in one book after another, originally in fact rather a matter of conjecture, based upon the idea that fungic propagation must be on exactly parallel lines with known biologic processes of a botanic order.

The house-fly fungus seems to have a superficial resemblance to some of the common "moulds," but mycologically examined there is good reason for classifying it with a family (Entomophthorea), which may be capable of an alternative form of fructificative development.

The originating germ somehow at some time must be supposed to have effected a lodgment in the body of the fly or possibly that of the maggot. Later on, one cannot say when, fungic spawn (a pulpous mycelium) starts a course of development, invades every part of the body, quickly kills the fly, and fixes it to the spot to which in its last moments it has crawled, often a window-pane. Its corpse is now swollen with the spawn developed into masses termed hyphal; but these should not be called hyphal (thread) but quasi-sclerotia, bodies intermediate in a process of normal development between the mycelium and the fruiting stage; fungic fructification ensues with great 
rapidity; and the corpse becomes suffused with an appearance of white mouldy excrescences, filiform conidiophores, of which the club-like tips make a copious ærial discharge of white spores; when these adhere to a glass or window-pane they imprint thereon a remarkable halo. Attempts to artificially infect other flies with these spores are common failures or have led to contrary conclusions.

The period from the first symptoms of distress to the death of the fly, and from that time to the spore discharge is wonderfully short. The infectious germs may have been long dormant in the fly, and very likely may have been acquired in the maggot stage. In the absence of exact knowledge, we can only make conjectures from observations of some kindred fungic parasites, which are not very uncommon amongst the chrysalids of certain moths, beetles, and the pupæ of some annual wild bees. In these cases it seems very unlikely that the infection was incurred otherwise than in the caterpillar or larval feeding stage. Dampness and insanitary conditions seem to favour the spreading of such disease, especially amongst artificially reared larvæ when crowded together and closely confined.

Other kinds of flies do not, so often as the housefly, perish from Empusa musca, but I have seen a common yellow cowdung-fly, as early as June, thus affected.

In spite of all antagonists the brood of the housefly flourishes and multiplies, but this is because great opportunity and encouragement is provided by the neglect of good sanitation by mankind. 


\section{CHAPTER IX}

\section{DISSEMINATORS OF DISEASE}

The house-fly may seem at first much less to be dreaded than any one of the painfully "biting" or (to be correct) skin-piercing and blood-sucking flies; yet it should be regarded as a much greater enemy to humanity and a more dangerous peril than any of those other flies, of which some short mention and description has now been given. Its life-history and its fecundity have been already alluded to; its rapid growth and maturity counterbalance the fact that it is short lived.

From ancient times there has been a consensus of opinion that there was in some way a connection of cause and effect between swarms of flies and the spread of disease. In the plagues of Egypt, in the reign of Pharaoh of the Exodus, it will be remembered how, after "the land was corrupted by reason of the swarms of flies," Exodus viii, 24, there came "a very grievous murrain" upon cattle, Exodus ix. 3, followed by a "plague of boils and blains" upon man and beast.

In our present day insect life is being scientifically investigated with the view of establishing the connection, and of discovering fully the serious roble of disseminating disease, of which the house-fly has long 
been suspect. The microscope reveals much, and the art of bacterial culture now explains how it is true that the superabundant creature, which has persistently followed civilised man into every quarter of the globe, has ever had a share in conveying contagion beyond that of any other household pest.

That the house-fly is bred in filth matters not much. After emerging from the puparium its first voidance of fæcal matter may be contaminated with live baneful germs, but it voids itself before its first flight. Having six legs it stands upon two pairs, whilst with the other pairs, at one time the front pair and at another time the hind pair, it works frequently and vigorously at brushing and stroking down every part of its body. Though it starts its new life quite a wholesome newborn creature, and though it must be credited with being a most assiduous remover of dirt from its own body, yet from the human point of view its subsequent life is a persistently disgraceful career.

It is the evil course of the newly-hatched and selfcleaned fly not to restrict its diet to the honey of flowers, as do some of its relations. Its food includes excrement, sputum, and every kind of putrefying organic matter likely to be swarming with microorganisms of a character deleterious to humanity. It is certain that, when only a few days old, a fly will practically abound internally and externally (on the feet) with dangerous germs, as amply proved by methods of laboratory culture. As it feeds, it walks over the fond; and the hairy joints of its feet, when microscopically viewed, appear conspicuously liable to carry germs in spite of frequent attempts at self- 
cleaning. Wherever it alights and walks, it prospects with a touch of its trunk, which is the main instrument of evil. It has a very filthy habit, from time to time, of depositing pale vomit spots as well as dark-coloured fæcal droppings. These defilements are visible, wherever it may alight on walls, windows, ceilings, and especially on pendent ornaments, whereon the males delight to rest.

Its manner of feeding upon solid food is to pour forth a copious supply of saliva, to regurgitate some previously imbibed fluid draught, and then to reimbibe ; thus, besides devouring soft food, it dissolves, befouls, and feeds on crystalline sugar and other hard dry food materials.

Its regurgitated fluid commonly swarms with bacteria, microbes, and the like. Imbibed bacteria are not inevitably killed in the digestive process of the fly, for its excrement has been found to abound with well recognisable infective germs. In the market, the shop, the larder, and on our tables, the house-fly seeks every opportunity of befouling and contaminating human food.

The varieties of micro-organisms are multitudinous, doubtless many more in number than the microscopist and the bacteriologist expert have yet isolated and registered as capable of identification. Granted that the majority of these are non-pathogenic to humanity, still a formidable number, including some which are very generally disseminated, are virulently pathogenic, and many are suspect. There is no need to give a list of all the infectious diseases which man and beast are liable to contract, but the germs of nearly all may be 
carried from place to place, from creature to creature, and from person to person, through the intervention or agency of the house-fly. The medical profession are convinced that infantile mortality from epidemic diarrhœea must be attributable to summer flies.

In the matter of food which becomes fly-infected after having been cooked, or of food like milk, butter, and fruit, which are consumed raw, it should be known that a single pathogenic germ of ultra-microscopic dimensions, having obtained lodgment in the body, may there multiply and originate a fatal disease. On the other hand, raw meat which has been infected may, after the bacteria have been all killed by cooking, contain excreted poison in deleterious quantity. The decomposition of infected meat begins ten or twelve hours before the bad odour is perceptible.

Fortunately the omnipresent germs which most commonly deteriorate our food are not very actively deleterious, or are only slightly debilitating; yet wherever such less obnoxious germs get lodgment, there the ready prepared and most favourable breeding place for the worser kind is to be found. The various species of these evil things are not always exterminating competitors; they sometimes flourish in company, and dwell together, like the seven devils within the exorcised and sane man after his relapse, as mentioned in the Scripture.

That food gets fly-blown and maggot-infected is a very disgusting fact, but the plainly visible result is of little hygienic significance apart from the more concealed facts of the fly-borne conveyance of zymotic diseases. 
Internal protozoal parasites and parasitic worms breed in and are disseminated by the house-fly ; so also are the fungic spores of fermentive yeasts, of moulds, and the like, but these latter are mainly disseminated by mere air currents. The eggs of tape-worms and the like are carried by dung-frequenting flies to food, especially to semi-putrid food devoured by dogs and pigs.

Some of the skin-piercing and blood-sucking flies are pestiferous in a more direct way than any of the tribes of filth and sweat-flies. They are the usual or suspected agents whereby anthrax. cattle-plague, swine fever, glanders, and other diseases are spread far and wide. Some of these last blood-sucking flies will travel with and on the bodies of transported animals for long distances; of course there can be no doubt also as to the capability of disease dissemination by the direct independent flight of flies to long distances with favouring weather and breeze. Such evils are prevalent throughout the temperate zones, but circumstances are far worse in the tropics, where Glossina morsitans, considered by some to be a near relation of our Stomoxys calcitrans, transmits the microscopic trypansomes which cause the devastating "sleeping sickness" of mid-Africa. This last reference, and other discoveries of the fly-borne germs of recurrent fevers, should bring into prominent notice a very pertinent fact; which has not yet received adequate scientific investigation. All the bites of our common blood-sucking insects, flies, gnats, midges, fleas, etc., are each kind of them wounds, sometimes very inflammatory, sometimes but little or not at all so; 
furthermore, the worst inflammatory wounds not uncommonly show feverish symptoms of a well marked periodic character, quiescent intervals being followed by revived inflammation in the same spot. These facts almost prove, or at least strongly suggest, an explanation that in the latter cases the source of pathogenic trouble is of a microbic character, and that periodic recurrence of feverish and inflammatory symptons is the time of the spore-swarming of breeding microbes; the difference between these latter and those of a more severe and often fatal kind in the tropics being that the one class finds the human body a fit host in which to multiply but the other class does not, and accordingly the latter grow weaker until their breed dies out. Similar effects can be observed in cattle and other animals, but all creatures, after suffering much from flybites at first, afterwards become for a time more or less immune. 


\section{CHAPTER $\mathrm{X}$ \\ REMEDIAL MEASURES}

We have seen in Chapter VIII that the checks which Nature has imposed upon the prolific breeding of the house-fly have been insufficient to protect civilised mankind from ancient times continuously up to the present day. This defect need now no longer be endured; but, alas, communities and individuals are ever slow to be warned, and averse to practise newly advised methods of sanitation. In few other directions is there greater promise of advancement in general public health and comfort than by preventive measures against the breeding of the house-fly. Effective measures comprehensible to all who consider the subject are so easy of application, that, if universally carried out, the house-fly might become a rare insect in a very few years' time. It is, however, of fundamental importance that the public should be made to comprehend the case; else the power necessary for enforcing suitable regulations by the local authorities will not be obtainable.

Preventive measures must constitute the supreme objective of an anti-fly crusade. The habits of the house-fly and its life-history make it clear how successful breeding may be prevented. The breeding places are local and accessible; the food substances of the larvæ are capable of being put under control ; 
and the maggot stage is the opportune period wherein the fly plague is most obviously open to attack.

In all town and suburban parishes a house to house collection of domestic refuse and garbage must be made, not weekly, but bi-weekly in summer, and the material must be cremated in a dust destructor furnace within a few days of its collection; thus neither larvæ nor pupæ therein would survive; no alternative disposal otherwise than by cremation should be attempted. Furthermore, and above all else, only refuse collecting bins of an authorised pattern should be employed. Contrary to the prevalent idea these should not be fly-proof and not have air-tight covers; they should freely admit air all round and should encourage the access of breeding flies. They should stand preferably in open daylight places and should be egg-traps for flies which, thus encouraged, would hardly erer deposit their eggs elsewhere; the result would be that all maggots and pupæ would be inevitably cremated.

It may be objected that, if open dust-bins are used, house-flies after visiting the same may return to the house and subsequently contaminate food in the larder. There will be such a possibility, but the danger thereof can be minimised, and would in fact be nearly automatically cured, as prospective fly progeny perished. Furthermore, there are circumstances which indicate that the said danger would not be great, and anyhow nothing comparable to the baneful effects which are now endured. The worst germs are not those of newly discarded food remnants ; the commonest and well-known bad smelling germ of ordinarily "tainted" 
meat, which is exceptionally attractive to the housefly and the blue-bottle, is fortunately, after cooking, not so dangerous as some of those other deleterious microorganisms mentioned in the last chapter. Taking one thing with another the balance of benefits and disadvantages will incline overwhelmingly in favour of open dust-bins, wherein food remnants may purposely become fly-blown. An improved dust-bin lid has been contrived which combines with the cover a centrally held wire-gauze "balloon" fly-trap, wherein flies will congregate and be imprisoned when attempting to leave.

Unfortunately air-tight dust-bins have been very generally recommended as a grand device of hygienic value; hence it is most necessary that unthinking people at large should be informed how much better it is to use open bins which can catch and secure for destruction prospective fly-broods. It may be asked-why not trap and kill the breeding females? The reply is that to do so will be good, as is to be explained in the next chapter; but contrivances for the latter procedure are apt to be less effectively put into general operation.

The fly swarms of mews, arising from accumulations of stable manure, will be difficult to alleviate without stringently enforced measures, but it is a mistaken notion to believe that town flies are bred in stables to such an extent that the invaders of our dwellings and town restaurants, shops, and markets, are merely or mainly the overflow of the mews. The concentration of many kinds of flies is very dense around ill-kept mews, and in midsummer-time a large percentage will be true house-flies. Frequent removal and cremation 
of stable manure would be quite effectual, but there is reason to think that, if proper care be taken, no such drastic procedure as cremation will be absolutely necessary, unless perhaps for the months of July and August.

There are two matters involved in sanitary stable reform-one is the proper structure of the stable floor and the treatment of the litter whilst in use for bedding; the other is the disposal of the horse droppings and the discarded litter called stable manure. If the floor be good and the bedding be well kept and fairly dry, which is often not the case, then the effective breeding of flies will be in the dung-pit and the external manure heap. From a sanitary point of view these latter are indeed almost everywhere ill-kept.

The general fate of maggots living on the floor of well-kept horse-boxes is to end their lives drowned in the drains to which they descend, when or before they pupate.

In these days of motor-cars and fewer horses the horticulturist everywhere is eager to buy good stuff; now stable manure to be good must be fresh and free from the garbage with which stable men wantonly corrupt the same, instead of consigning such extraneous refuse to a proper separate dust-bin for collection and cremation. So much can be done remuneratively with a regular supply of clean fresh manure, that it seems almost worth while transgressing the proper limits of this booklet and writing chapters on mushroom culture and on the intensive hot-bed cultivation, with the aid of "cloches" or bell glasses, called French gardening. It may be thought that such cultures will of themselves 
breed swarms of flies. Though such is not necessarily the case, the liability by common carelessness is very great.

The expert horticulturist has a special preparatory treatment for fresh manure intended for hot-beds; new manure in heaps rapidly "heats," and is ærated by being turned over two or three times on separate days before being packed close for the hot-bed. This process of treatment rather disagrees with the breeding of the house-fly. Mushrooms and all the fungus tribe breathe by inhaling oxygen and exhaling carbon dioxide; and so it happens that even insects which delight to feed on mushrooms, are somewhat repelled by the special atmosphere of very actively growing mycelium or spawn.

The amateur entomologist and the nature-student will observe that the flies which pester the gardener at work are mainly other than the common house-fly. The reader, nevertheless, will like to know if something more cannot be done to stable manure for exterminating maggots, whether of house-flies or the many various filth flies, already hatched and growing therein. Well, "something" indeed can be done by the use of some insecticide. Hitherto chloride of lime has been employed, but the most approved insecticide for the purpose is a solution of iron sulphate-two pounds in one gallon of water; this is said not to deteriorate the horticultural value of stable manure. However, in fine weather, the spreading out and drying of freshly received manure practically rids it of fly maggots, which cannot survive this simple procedure. The mere burial of fly-blown dung and stable litter without prior treat 
ment is quite inefficient. Insanitary heaps of neglected manure, which terribly swarm with maggots, much deteriorate in horticultural value.

Farmyards and the scattered dwellings of rural districts remain to be considered, and no doubt herein the difficulty is great, but not hopeless. The latter will be persuaded to follow suit when the good effects of town and suburban policy become apparent.

Something more than usual is desirable for the protection of cattle from the breeze and the œstrid flies at midsummer. The latter, at all events, could be easily exterminated by giving butterfly nets and encouragement to children, who would enjoy the fun. Although the close approach of strangers may alarm grazing animals, after the latter have galloped away a very good chance will occur of capturing the slow flying gravid female worble-fly with a butterfly net, or of felling her to the ground with a suitable instrument; if missed on the first attempt, other chances can be got again and again by waiting until the said same fly has returned to threaten her intended victims. The writer has often succeeded in felling the slow flying gravid female worble-fly with a mere walking stick. It is strange that no farmers' entomological friend has hitherto suggested so common-sense a remedy as butterfly nets, which should be of a dark green colour. A company of our popular boy scouts, marching in a skirmishing line on an August Bank Holiday (or a preceding Saturday), over ground where grazing animals are observed showing behaviour conspicuously indicative of attacks by œstrid flies, would 
enjoy doing grandly useful execution. Every capture should be substantially rewarded.

In an organised campaign of house-fly extermination it may rather be expected that the principal trouble will be with the stable men of unsanatory mews. In the United States of America very stringent byelaws have been made and enforced. Some of these, perhaps, deserve consideration for adoption, with judicious improvements, in England, but the policy of the OPEN DUST-BIN and CREMATION raises new hopes of success far beyond any advantages hitherto obtained in America. 


\section{CHAPTER XI}

\section{CONTROL WITHIN THE HOUSE}

Many minor plans have been proposed for obviating or alleviating the perils and plague of invading fly swarms ; several such plans may be well carried out on a private domestic scale, but one cannot expect any of them to be adopted universally. In domestic methods people will prefer some one plan, some another, whilst some will not personally aid in the work of fly destruction in any single way perseveringly. This latter circumstance emphasises the necessity of a dominant control by local authority for the safeguarding of all inhabitants, including the delinquents themselves in spite of themselves.

The plan, as detailed in the last chapter, of enticing breeding females to lay their eggs within depositories of discarded food remnants and garbage, can be practised on a smaller scale with great advantage everywhere. Kitchen refuse of many kinds, not neglecting potato and turnip parings, cabbage leaves, or even tea leaves, should all be collected in brown paper bags, which should be left open for a few days in suitable places round about the house for the free access of gravid female house-flies. Every such collection should be cremated on the third day. In a paper, read at a recent congress of the Royal Sanitary Institute, on 
"Destruction and Prevention of Household Pests," Dr. Gay advised rich and poor, in every household, whether or not a sanitary dust-bin was in use, instantly to wrap up in paper all such fly-breeding materials in readiness for cremation. However, to do so would be missing the much more effectual course of applying my "egg-trap" plan of collections in exposed open bags for cremation on the third day.

For indoor use insecticide methods are more suited; and the best of these are immensely more effective than some popular devices, which make a remarkable display and sell well, but which the purchasers soon become neglectful to keep in constant use. Traps in the form of wire-gauze cages, and glass non-return bottles belong to this latter class of contrivances; when seen crowded with struggling victims, the employment of such articles captivates many observers; but their real efficiency will be found to fall far short of general expectation. The explanation will be apparent when the use of the wire-cage trap is contrasted with the success of a good fly poison. Given, say, a dwelling room on a midsummer day containing ten female flies and ten idle dancing male flies; in such cases not more than half the females and one quarter of the males will get imprisoned within four or five hours by the employment of the wire-cage trap, but with a good method of setting poison nine-tenths of the females and half the males may be killed within the same period. In the case of poisoning, the dead have to be swept up, whilst fly traps have the advantage of collecting the victims; but, unless the inmates are carefully destroyed, a few will manage sometimes to 
escape from the traps, especially as side window light changes and daylight fades. In these fly traps it is only the perseverance of the prisoners in struggling towards outer light which prevents their exit by the entrance aperture.

Stickfast adhesive papers and suspended tapes and strings look very effective when seen crowded with accumulated captures ; but, again, these "exhibition" appearances are as deceptive in suggestions of real efficiency as are the crowded cage traps last mentioned; moreover, sticky messes are not commendable or convenient articles for placing where most wanted. Truly, suspensory strings are attractive resting resorts for dancing males, but the worst agents of Beelzebub are the females, which have a keener appetite for food and for pestering humanity.

There remain for consideration insecticide poisons. A great choice of materials can be supplied by the chemist's shop, and various methods of using them have been recommended. In old times country people prepared decoctions of Amanita muscaria, the fly toadstool, a large orange-scarlet, or crimson, mushroomshaped fungus commonly appearing in autumn in woods where birch trees abound. Strange to say, such decoction will poison flies of many kinds, although they, and many different creatures, feed with impunity on other fungi which are more deadly poisonous to mankind.

Effective poisons are such good exterminators of flies, that the main consideration is how to safely and most suitably employ them. There are some people who have an invincible aversion to the mere thought 
of poison purposely administered by way of food or drink, though possibly they do not have an equally strong repugnance to the use of insecticides used for stifling. However, one cannot help running counter to much misplaced sentimental humanitarianism in some people on some subjects ; reasons and arguments will not move them, for they do not wish to think otherwise than as their prejudices influence them. The house-fly is itself a poisoner of our food, and it, or rather she (the offender being nearly always female), is a more dangerous and a more subtilely baneful enemy than, for instance, the human flea, which even the Brahmans or the disciples of Buddha may kill.

Fumigatory insecticides, though occasionally useful, may be left out of consideration in discussing the rival merits of means in a warfare against the house-fly.

A liquid or moist food poison employed in a safe and effective way will excel every other weapon of warfare within the house. One of the newest recommended substances is formalin, which has the advantages of being a disinfectant, a strong fly-poison not avoided by flies, and not dangerous or attractive to clomestic animals. A tablespoonful of (40 per cent.) formalin should be mixed with one half pint of milk and water; this, when exposed in saucers or shallow dishes, is said to be an attractive and a fatal bait. It would be evidently dangerous and objectionable to use some other commoner poisons in the same way; but it is the opinion of some users that formalin and milk is not sufficiently alluring.

Contrary to a generally prevalent idea a powerful odour is not required as an indoor allurement for the 
common house-fly; again, a saucer or shallow dish with liquid contents is not a good method of presenting the fatal bait. Placed on a table, or on a window sill, or on a shelf, a saucer is liable to be tipped up and its contents spilt; moreover, the form of such receptacles is radically faulty by reason of the strenuous walking habits of the fly on the level. Out of many flies walking over a table ten or twelve may pass by, or round, an overhanging saucer's rim to one fly that will mount the same and sip inside. However, let such a saucer or plate be placed on a table upside-down, and let a slightly moist substance be placed in the shallow central depression, which ordinarily is the base, then the said ten or twelve flies will all mount and sample the moist substance, even though it be not apparently attractive in smell; an inclined plane is ever an irresistible invitation to mount and prospect the summit.

It is another great mistake to suppose that an extra tasty food material is desirable as a bait. The same kind of mistake is made by people baiting a mouse trap with toasted cheese, whilst a bit of dry bread, or better still, a green pea, would much better entice a common mouse. Strong smelling and saccharine foods immensely attract the blue-bottle and the wasp, which are thus enticed indoors and induced to become occasional visitors to our tables; but the house-fly requires little of such lures; indoors she is an inquisitive prospector, who will never pass by any moist material without testing its quality. Moreover, the use of poisoned milk, or even jam, should be rather avoided for fear of injury to dog or cat; furthermore, it is dangerous to place a piece of bread in a saucer of 
liquid fly-poison, as is sometimes done, to serve as a sop and as a standing stage. However, there is one good lure well worth mentioning; it is beer-dregs with or without a little sugar; moistened yeast is good, and the advantage of beer-dregs with just a little sugar is due to the mild yeast-like odour of slow fermentation, which may fail if formalin be the insecticide ingredient.

The handiest and safest preparation of fly-poison is that sold in the form of a dry flypaper, which is said to contain arsenic as the deadly ingredient. A very small piece of one of the sheets ordinarily sold should be placed on the summit of an inverted saucer; a mere spoonful of water now and then will suffice to moisten the same; there is little or no advantage in sprinkling a little sugar thereon, unless beer-dregs are added. This plan of using moistened poison paper is clean ; it is safer than using a more fluid bait, and the ingredient is certainly efficient; the slightest taste thereof by an inquisitive fly ensures its speedy death. Another poison which has been recommended is a strong decoction of tea-leaves, to which a little sugar and beer may perhaps be added.

It is said that the smell of geraniums is odious to the house-fly, and so pots of these plants may be grown beneficially on window-sills. Certain other odours and scents are believed to be likewise more or less fly deterrent, but their use is not effective warfare against fly propagation. Paraffin painted on window-sills is said to be very efficient.

Flies may be easily prevented from entering the open windows of any room, which has windows only on one side, by the use of venetian or louvre blinds or 
shutters, or of many kinds of screens, although the apertures thereof may allow of ample room for flies to pass to and fro. If, however, there be windows on two sides of a room, then venetian blinds and the like will be useless, and window screens must have very close meshes to be effective. The house-fly will pass through netting only when there is light shining on the further side. A knowledge of this fact is very important in the planning of hospital wards. In a sick room, if there be windows on two sides, one in summer time should be darkened when the other is open for ventilation.

The protection of the larder and the screening of food should never be neglected, but what is of even greater importance is the prevention of access by flies to fæcal matter, or to purulent and all unhealthy discharges from the sick room. 


\section{CHAPTER XII}

\section{THE SERVICE AND UTILITY OF FLIES}

It is often asked-have not house-flies some use in Nature? The only true answer is that they are warning signals.

They certainly do join with a multitude of other flies in promiscuous scavenging services, and they can be very active agents therein; but this work only aggravates the fact of their dangerous partiality to mankind, together with all his belongings and surroundings. These creatures may well be imagined to have developed out of some primæval species by reason of the increase of mankind upon this planet. The mere presence of the house-fly denotes some nuisance more or less remote; the local density of the brood indicates the degree and the proximity of unsanatory conditions. Under present circumstances the visitation of the house-fly is Nature's intimation that peril of a very insidious character is about. Very properly, Nature's messenger will not be denied, and pertinaciously manifests herself to us indoors!

It has already been explained that the scavenging service of the house-fly can be altogether dispensed with, inasmuch as there is a sufficiency of other less noxious flies and creatures devoted to such work. Reflecting on the Story of Creation, and the mission of man as 
first a gardener, and then, when expelled from Paradise, destined to more laboriously cultivate the earth, it may be held to be man's allotted duty not only to wage war against weeds, but likewise to distinguish friends and foes of all kinds, and treat accordingly creatures even of all branches of the animal kingdom, whether insects, reptiles, birds, or mammals, favouring one and exterminating another. This will be to rule the earth and "subdue it" (Genesis i. 28). Nemesis will inevitably chastise man unless he rectifies the consequences of his own delinquencies, whether they be direct or indirect. The "good service" of the house-fly is comparable with that of the flea, which performs an unwelcomed and indirect "service," inciting the housewife to have well-swept floors and clean bedding.

The unalloyed good service of insectivorous flies is quite apparent. The details of their life-history and a description of their different characteristics would make an interesting volume, but the limitations of the present work preclude such enlargement of its scope.

It certainly stands to the credit of the blue-bottle that she is by far our best native scavenger of carrion; so good, indeed, that none other as an assistant is needed. She may just possibly sometimes convey germs and contaminate food, but she does not so directly assail man. Her larger size makes her easy for exclusion from the domestic food store. So eager and alert is the female in searching for meat, dead animals, and fish, that our other native carrion-feeding flies are at a great disadvantage in the struggle for existence; so prompt is she in monopolising carrion, that would- 
be competitors often have to be content with laying their eggs in less rich food materials. The blue-bottle can withstand temperatures a few degrees colder than can those flies to which she is nearest akin; and she seems capable somehow of sheltering herself better. Even as late as the middle of winter, sometimes, a dead bird may be found to be fly-blown under circumstances which indicate that the eggs must have been laid in frosty weather, when flies are not seen at large. The explanation is that the blue-bottle will for a short time awake, and venture outside her retreat in a sheltered south wall, warmed by a few hours of winter sun. She. does not hibernate in early winter in such a continuous state of rigid torpor as, for instance, does the queen wasp ; probably few or none survive the winter by a real hibernation, the progenitors of the first spring broods emerging at a date no earlier than do their rivals and congeners.

As a bird food or a fishing bait gentles are superior to the maggots of any other dipterid insect. So-called ants' eggs and meal-worms are more highly appreciated by the fancier for bird food, but they are expensive. The pupæ called "ants' eggs" can only be had fresh for a short period of summer, and dried stock for the rest of the year requires much labour to obtain and prepare. Meal-worms are the cleanest and the easiest to propagate of all similar larva ; but they are very slow growing compared with gentles; in the natural state the life-cycle from the egg to the feeding worm, then the pupa or chrysalid, and finally the bettle, Tenebrio molitor, occupies a twelvemonth's time; but, like many other insects which have accommodated themselves to 
human surroundings, they can increase more rapidly. By rearing a number of broods, each in a separate vessel, and by hastening the development and propagation of some broods more than others, meal-worms may be obtained fresh throughout the year ; the amount of trouble and attention required is accordingly great.

The artificial rearing of gentles is easy, rapid, and cheap. Generally it is not well or methodically managed, and consequently it is then a horribly malodorous nuisance. However, with proper care the process can be managed without offensiveness, and it will immensely repay all trouble.

A more restricted variety of birds relish gentles, but no insect food is more wholesome for any of the galinaceous tribe.

A spot in the open air, preferably sheltered from the north or east wind and from mid-day sun, should be chosen. There an inverted earthenware sea-kale pot or a similar vessel should be fixed on a stand or table twenty inches high from the ground; the table should have a central hole corresponding to that in the sea-kale pot. The hole in the pot should be obstructed with a wire-cage strainer, or a piece of perforated wood or metal, above which a few sticks or a bunch

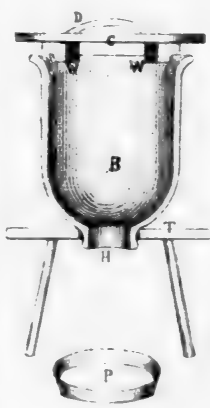

Fig. 6.

Apparatus for the cleaner breeding of gentles. of straw may be placed.

Fly-blown dead animals, fish, offal, or suitable food remnants should be placed from time to time in such a receptacle, which should be surmounted with a 
removable rain-proof cover and shade of ample size. The latter should allow a two-inch space or a little more underneath all around the rim of the pot for ventilation. Underneath the table or stand a wide and more or less shallow pan or dish should be placed, and a little clean sharp sand placed therein.

The gentles, whilst growing and feeding, are called " green" gentles; their skin is transparent, and in this state chickens do not like eating them; and it is as well so, for then the half-grown gentles would be capable of temporarily becoming deleterious internal parasites in the birds' crop. As soon as they are full grown they crawl away from the food material and will fall through the strainer-like obstruction in the bottom hole of the pot into the pan on the ground underneath. They are then termed clean or "scoured" gentles and are fit for bird-food or for fishing-bait.

If taken out of the pan and placed in boxes with a little sand, they will keep three days, more or less, according to the weather; they then pupate, and in a few days, or weeks, or months, according to temperature, emerge as blue-bottles. As pupæ they are good and convenient food for domestic fowls, and for all pheasants and like game-birds.

If receptacles as above directed are situate in a fowlrun, the hens will never leave the ground dish unwatched as long as full fed gentles are maturing. Hens thus fed are prolific layers of eggs, but of course they must be otherwise fairly fed with farinaceous and suitable other food and healthy grit. The maggots of no other flies are worth similarly cultivating; those that feed on vegetable refuse are more offensive in 
smell than common gentles; the maggots of the fungus flies are comparatively clean creatures and free from bad smell, but the largest are small. 


\section{CHAPTER XIII}

\section{A CAMPAIGN OF EFFECTIVE WARFARE}

Several authors of recent books, and lately also able lecturers, have done much to awaken people to a realisation of the dangers of our ever recurrent summer plague of flies. The advent of the petrol motor-car and other automobile vehicles has at the most but very slightly improved the state of affairs within town areas, where mews were formerly much more numerous. The public press has followed suit, but something more in the way of a sustained effort for hygienic reform is desirable. The terrible European war should not preclude consideration of the subject, for the scourges of fly-borne contagion have ever followed armies and rivalled the casualties of the very battlefield. Bands of enthusiasts everywhere should keep going a veritable anti-fly campaign as one of the most urgent needs of practical sanitation. Otherwise active support of the cause will soon languish and be obliterated amongst the multitudinous ever-changing questions of the day, political and other, which, as newspaper editors are persuaded, have the attention of the public for the time being. In spite of the incontestible prospects of universal benefit it may not be easy to engage a large body of public support without something like an organised propagandist movement.

If any readers of this booklet are disposed to join 
and form a central body with a view of ultimately founding an association for promoting the work of fly extermination, the writer will be glad to find or meet with an honorary secretary and helpers who will work in the cause and economise in the necessary expenditure of all contributions received. After the preliminary efforts of starting such an association, its work will be not only to urge the local sanitary authorities everywhere to adopt the best possible course of action, but also to incessantly move public cpinion to compel Parliament to pass laws, capable of administration, for the public welfare in this matter.

The present booklet had its origin very many years ago in the author's idea of writing an account of the house-fly and its kindred, which would be interesting and more truthful than much then to be found in current literature. Such off-hand inconsiderate writing, as appears in the "Elements of Entomology," by W. S. Dallas, F.L.S., requires to be controverted; therein it is stated that the house-fly, which is "troublesome, does very little actual damage, for our only real grounds of complaint are to be summed up in the tickling sensation which its feet cause," \&c. "In its larvæ state, however, it lives inoffensively enough in dung." It has now seemed timely to publish my long-delayed work, re-written with the object of more urgently interesting the general public in the cause of the anti-fly campaign. Still, the author trusts that both the deeper and the less entomologically inclined nature students will find therein not only useful, but also some novel information, given with not too much entomological technicality. 
There is no English work sufficiently modern and comprehensive for a study of our native flies. In 1776, Moses Harris, who originated or elaborated the study of wing patterns, published his "Exposition of English Insects," in which more than 300 flies are figured and described ; they have the old Linnæan classification and nomenclature, of course, and the work is scarce. All later attempts by English authors in the way of a more comprehensive student's guide book have been left incomplete. Another excellent, but expensive work, Curtis's "Genera of British Insects," contains about 250 illustrations and descriptions of flies; but most of these are rather rarities, and the amateur in search of a facile guide to the commoner objects of the countryside will be apt to be disappointed. For the sake of readers possibly eager of advancing further in the study, and in the absence of any commendable guide book, a short appendix has been added to the present work, for help in identifying more numerous species and those of many families and genera not mentioned in the foregoing pages. With the leave of the Northumberland, Durham, and Newcastle-upon-Tyne Natural History Society some valuable plates of illustrations are herewith reprinted, and explanatory notes are added, mainly from the volume of the Society's transactions for 1906, a most valuable work and compilation by the late Rev. W. J. Wingate, of Bishop Auckland. This learned entomologist has succeeded in giving a marvellously comprehensive amount of clear condensed guidance. It is a great privilege that the present booklet has been allowed to borrow from such a source 
of knowledge, valuable far beyond the locality of its authorship.

Other illustrations which have been borrowed appear with the leave of His Majesty's Office of Works, out of Reports to the Local Government on Public Health and Medical Subjects. 


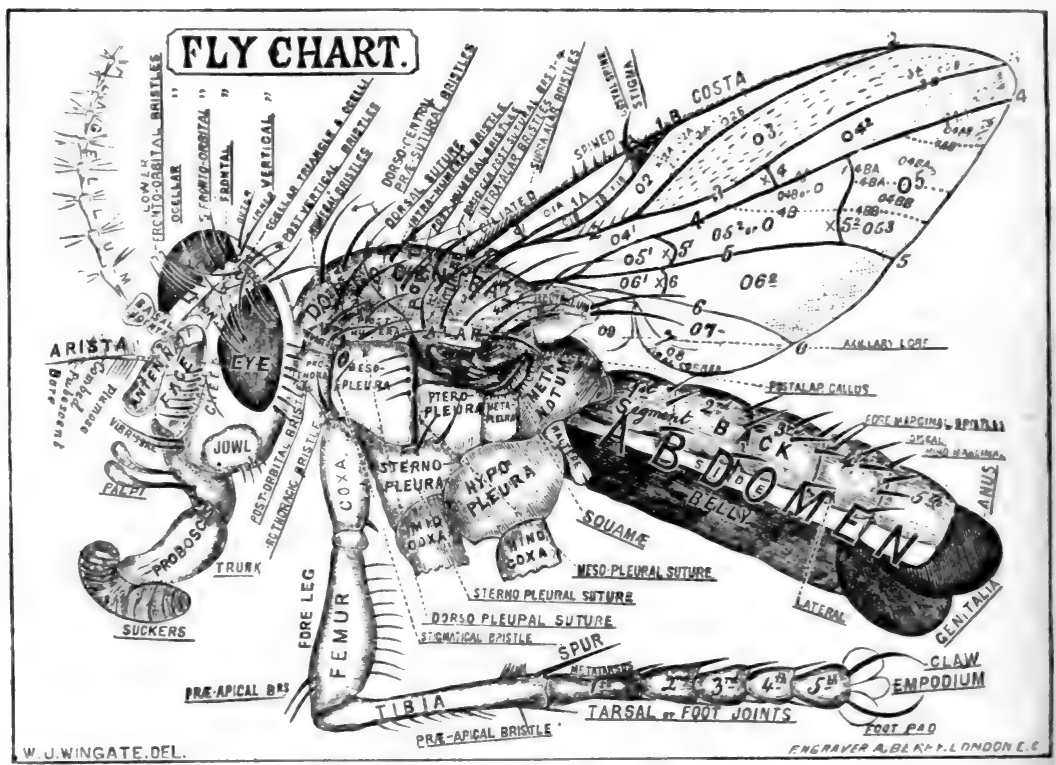

Plate I. (APPENDIX) 


\title{
APPENDIX
}

\section{INDEX TO TERMS AND SYMBOLS}

\author{
OF THE
}

\section{WINGATE FLY CHART, PLATE I.}

THIS Index, together with the following "Table of Wing-cells and Veins," the "Glossary," and plates, II, III, IV, V, VI and VII, will explain the theoretical Diagram entitled The Fly Chart, illustrating characteristic features and exterior parts, by the study of which the reader may learn to differentiate all the sixty families which contain species native to Great Britain.

E $A=$ the Head, comprising nine regions and parts (A, I to $A, I X)$.

A, I, the Vertex, which contains (I) the Ocellar Triangle; (2) the Ocelli; (3) the Vertical Triangle, a coloured patch surrounding the ocellar triangle; $(7)$ the Vertical Orbit, the sides of the vertex close to the compound eyes. The Bristles hereabouts are (4) the Vertical (inner and outer); (5) the Post-vertical; and (6) the Ocellar.

A, II, the Compound Eyes, large and often hairy.

A, III, the Frons is the forehead between the eyes; it contains (I) the Frontal Stripe; (2) the Frontal Orbits at the sides of the frontal stripe; (3) the Frontal Lunule (platc VII, 5) a crescent immediately above the antennæ. The Bristles hereabouts are (4) one pair of Frontal; a row, or rows of (5) Fronto-orbital; and (6) Lower Fronto-orbital. The (7) Eye Margin is a narrow, often glistening, white line close to the eye.

A, IV, Antennæ, jointed processes springing from between the eyes just below the frons; those with numerous joints are illustrated in plate II, others in plate III. The Frontal Suture in the middle of the face is a little pit in which short antennæ often lie close together. The (1) Basal Joints are the two next the head; (2) the Flagellum, all the joints, when numerous, taken together; (3) the First Joint is next the head; (4) the Second Joint; (5) the third Joint (plate III, I-9) is sometimes ringed; (6) the Arista, or Seta, is a plume, spine, or bristle springing from the third joint at some point of its upper surface between the base and the tip. 
$\mathrm{A}, \mathrm{V}$, the Face is the region above the so-called mouth and below the antennæ; the ridges bounding the face on each side are (I) the Facialia ; here are (2) the Facial Bristles; (3) the Mystax (pl. VI, fig. 28) is peculiar.

A, VI, the Cheeks, spaces at the sides between A, II and A, V(I).

A, VII, the Jowls, parts below A, VI and the so-called mouth.

A, VIII, the Mouth, more or less of a cavity into which (3) the Proboscis (the jointed sucking trunk) can be sometimes partly withdrawn; the proboscis has a basal joint called the Rostrum (a snout); the other joint is called the Haustellum (a pump) and has the tip variously adapted as for mere surface suction, or for deep ínsertion, or for piercing. (I) the Peristome is the region surrounding the mouth; $(2)$ the Vibrissæ are strong bristles close to the sides of the mouth, or A, V (I); (4) the Palpi, two feelers (or perhaps smelling organs) attached to the proboscis.

A, IX, the Back of the Head; here (I) Post-orbital Bristles are sometimes found, that is to say, behind the eyes, A, II.

$\mathbf{B}=$ the Thorax, the middle portion of the fly bearing the organs of locomotion.

B, I, the Dorsum. The diagram on plate VI, fis. 40 illustrates the upper surface of this region; this part is bounded in front by $(a)$ the Neck; behind by (b) the Scutellar Suture (I5) or Seam; at the sides by (c) the Dorso-pleural Sutures (9-9) running from the front corners to the front of the Wing Bases; by $(d)$ the Wing Bases (I0-10); and by (e) the Scutellar Bridges, which are ridges (II-II) running with right and left inclines to the root of (6) the Scutellum. The Dorsum is crossed by (8) the Dorsal Suture, behind which are the Alar Regions (5-5); here on each side is a ridge (12-12) the Alar Frenum; rows of minute bristles on the centre are termed Acrostichal.

B, II, the Sides, or Pleuræ, specified separately in connection with-

B, III, the Brest, or Sternum; (I) the Prothorax is below the shoulder and above the fore-leg; (2) the Meso-pleura is contiguous to the prothorax and the shoulder; here in the upper front corner is the "Stigma," a prominent respiratory orifice, below which the large Stigmatical Bristle may be found; the (3) Ptero-pleura is below the wings and behind the meso-pleura; (4) the Meta-pleura is "a more or less tubercular piece below the region between the root of the wing and the haltere"; (5) the Sterno-pleura is above the middle leg and below the Sterno-pleural Suture, where it 
bounds the meso-pleura; (6) the Hypo-pleura is behind the sterno-pleura and above the hind leg.

$B, I V$, the Meta-Notum is the part of the thorax behind and beneath $\mathrm{B}, \mathrm{I}(6)$, the scutellum.

$\mathrm{C}=$ Appendages of the thorax.

C, I, Fore-legs, Mid-legs, and Hind-legs; every leg has nine joints [particularised illustrations on plate VII] ; (I) Coxæ are the joints attached to the body; (2) Trochanters very small and inconspicuous; (3) Femora or Thighs; (4) Tibiæ or Shins; (5) First Tarsal Joint or Metatarsus ; (6) Second Tarsal Joint ; (7) Third ; (8) Fourth; (9) Fifth Tarsal Joint; (I0) the Knees are where the Thighs and Shins join; (II) Claws, Foot-pads, and Empodium are appendages of the fifth tarsal joint.

C, II, Wings [sce Table of wing-cells and veins]; the quarters of the wing are the Fore and the Hind Basal Regions and the Fore and the Hind Apical Regions. The Stigma is a thickened portion of the wing at the middle of the fore margin.

C, III, the Halteres.

C, IV, Squamæ are scale-like appendages beneath the wings and above the halteres; they seem to have some attachment to the roots of the wings; a small inner lobe is called the antisquama, but it is a feature not of much use in classifying and differentiating species.

$\mathrm{D}=$ the Abdomen has numerous ringed sections; in the Sub-order, Cyclorrhapha in eight segments, but commonly divided into four or five conspicuous segments and three or four more smaller, less visible, and much modified in the sexual terminal segments.

D, I, the first abdominal segment is the Basal Segment.

D, II, the last of those more visible is the Anal Segment or Anus.

$\mathrm{D}, \mathrm{III}$, the abdominal termination, sce flatc VI, fig. 17.

D, IV, the chief segments consist each of an Upper Plate joined to an Under Plate by Membranous Sides, often concealed.

D, V, Abdominal Bristles, sec plate VI, fig. 4I.

$\mathbf{E}=$ Bristles, Hairs, etc.; fine short furry hairs are called Pubescence; "Hairs" are longer and stronger; Bristles are still stronger; but a very thick bristle is called a Spine, if on the costa, and a Spur, if on the leg; the larger bristles on B or on $\mathrm{D}$ are called Macrochætæ. 
$\mathrm{F}=$ Stripes and Bands; a long marking, when parallel (or nearly so) to the major axis of the body, leg, or wing, is called a Stripe; when lying at right angles (or nearly so) it is called a Band. For "frontal stripe" sce A, III (I).

$\mathrm{O}=$ Cells of the wing [sec the following Table]; the rib-like nervures are termed Veins; these divide the area of the wing into more or less twelve compartments called Cells or Areolets.

$\mathrm{V}=$ Longitudinal Veins [see the following Table]; two groupings within the margin can be recognised; the principal veins of the Fore Region are numbered, 1, 2, and 3, whilst those of the Hind Region are numbered, 4, 5, 6 and 7 respectively; some have branches, $a, b, c$, etc., when sections (separately referred to) may have index numerals attached.

$\mathrm{X}=$ Cross-Veins [sce the following Table] ; one very significant $\mathrm{X}$-vein termed X, 4 (or the Discal X) in the middle of the wing connects the longitudinal $\mathrm{V}, 4$ to the $\mathrm{V}, 3$, which are thus to be identified even in very abnormal patterns.

The cross-veins and cells are symbolised by having at tached to the letters $\mathrm{X}$ and $\mathrm{O}$ respectively the indicative and qualifying figures and letters belonging to the $\mathrm{V}$ upon which they rest, that is to say, the $\mathrm{V}$ (or part of $\mathrm{V}$ ) which is the lower boundary. 


\section{TABLE OF WING CELLS AND VEINS}

O, I.-Costal Cell (undivided), or Costal Areolet.

$\mathrm{O}, \mathrm{I} a^{1}$. - The Humeral Cell

O, I $a^{2}$. $\rightarrow$ Second Costal Cell $\}$ Costal Cell, when divided.

O, I $b$, - Subcostal Cell

$\mathrm{O}, 2$.-Marginal Cell (resting on $\mathrm{V}, 2$ ).

$\mathrm{O}, 3 .-$ Submarginal Cell (resting on V, 3).

$\mathrm{O}, 4^{1}$. - Cell resting on $4^{1}$ (the Ist part of $\mathrm{V}, 4$ ), a "basal" cell.

$\mathrm{O}, 4^{2}$.-Cell resting on $4^{2}$ (the 2nd part of $\mathrm{V}, 4$ ).

$\mathrm{O}, 4 b$. - Cell resting on $4 b$ (a lower branch of $\mathrm{V}, 4$ ).

$\mathrm{O}, 5^{1}$.-Cell resting on $5^{1}$ (the Ist part of $\mathrm{V}, 5$ ), a "basal" cell.

$\mathrm{O}, 5^{2}$. - Cell resting on $5^{2}$ (the 2nd part of $\mathrm{V}, 5$ ), a "discal " cell.

$\mathrm{O}, 5^{3}$.-Cell resting on $5^{3}$ (the 3 rd part of V, 5), a "marginal" cell.

O, 6.-The Anal Cell.

O, 7.- The Axillary Cell.

O, 8.-The Subaxillary Cell.

O, 9. - The Alula, or Axillary Lobe.

V, $c$ (or C). - The Costal Vein, or Costa, bounding the front Margin.

V, $c \mathbf{r} a$.-Part of the Costa (often ciliated and spined) reaching to the end of $\mathrm{V}, \mathrm{I} a$.

$\mathrm{V}, \mathrm{I} a .-$ The upper branch of the $\mathrm{V}, \mathrm{I}$.

$\mathrm{V}, \mathbf{I} b$. - The lower branch of the V, I.

V, 2.-Second (longitudinal) Vein.

$\mathrm{V}, 2$, - - Lower branch of $\mathrm{V}, 2$.

V, 3. - Third or Cubital Vein.

V, s.-The "Vena Spuria," a thickening of the wing (characteristic of Syrphidæ), an imperfect V between V, 3 and V, 4 crossing $\mathrm{X}, 4$.

$\mathrm{V}$, h.-A "Hang" V (or Appendix) a more or less irregular incomplete V.

$\mathrm{V}, 4$ - - Fourth Vein, often much branching.

V, 5.-Fifth Vein.

V, 6.-The Anal Vein.

V, 7.-The Axillary Vein.

$\mathrm{X}, \mathrm{I} a$. - The Humeral Cross-vein, connecting $\mathrm{V}, \mathrm{I} a$ to $\mathrm{V}, c$.

$\mathrm{X}, \mathbf{I} b$. - The Subcostal X-vein, connecting V, I $b$ to V, I $i$.

$\mathrm{X}, \mathbf{2}$.-Cross-vein connecting $\mathrm{V}, 2$ to $\mathrm{V}, \mathrm{I} b$.

$\mathrm{X}$, 4.-Discal, Middle, or Central X-vein.

$\mathrm{X}, 5^{1}$. - Lower Cross-vein, connecting $\mathrm{V}, 5^{1}$ to $\mathrm{V}, 4$.

$\mathrm{X}, 5^{2}$.-Lower Marginal Cross-vein, connecting V, $5^{2}$, to V, 4 (or to some branch of $\mathrm{V}, 4)$.

$\mathrm{X}, 6$. - Anal Cross-vein. 


\section{REFERENCES}

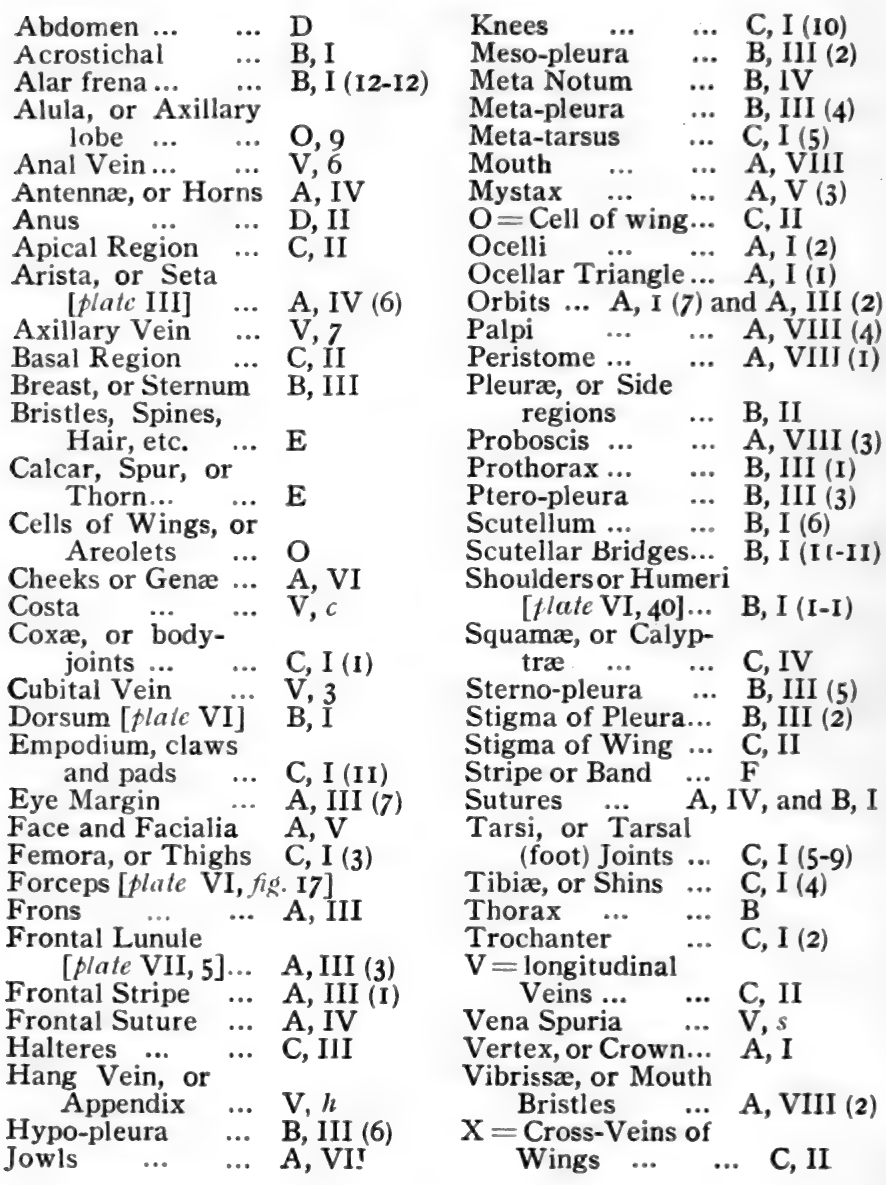




\section{ALPHABETIC LIST OF FAMILIES}

\begin{tabular}{|c|c|c|c|c|}
\hline ame & Family Analytic & Name & Fami & nal \\
\hline Agromyzidæ & 127,138 & Muscidæ. & 1 & 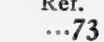 \\
\hline nyidæ & .XXXIII & Mycetophilidæ & ....III & ... I0 \\
\hline & XVIII & $\mathrm{Ny}$ & .LX & I 45 \\
\hline ... & .LV ... & CEs & & $\ldots 62$ \\
\hline & $\ldots$ II & the & 0 & I39 \\
\hline & $\ldots$ XIX ... & hilidæ & e...VII ... & $19 b$ \\
\hline & ...LVI ... & & ...XXI & 37,104 \\
\hline & $\ldots$ LIX ... & $e . .$. & ...LVII & 140 \\
\hline & $\ldots 3$ & $\mathrm{~d} x$ & e...XXXV & 9 , I I6 \\
\hline & $\ldots \mathrm{I} 4$ & & ...LIV & 68,125 \\
\hline & ...LI & & ...XLVII & 120 \\
\hline & ...XXIX & & ...XXVII & $\ldots 58$ \\
\hline & ...XXXIV & & ...XXVI & $\ldots 53$ \\
\hline & $\ldots 18$ & & .XXXIX & I0I, I35 \\
\hline & XXII & & ...VIII ... & ... I6 \\
\hline & $19 a$ & & ...XXI & $\ldots 2 \mathrm{I}$ \\
\hline didæ & ..XXIV & & ...I & $\ldots 0$ \\
\hline$d \mathfrak{d}$ & $\ldots$ II $4,13 \mathrm{I}$ & & ...XIV & ... 8 \\
\hline & $66 a$ & idæ & XLIV & $\ldots 93$ \\
\hline & ...XLIX & & $\ldots X X I$ & $\ldots 44$ \\
\hline & XLVIII & & $\mathrm{XXX}$ & 86,95 \\
\hline & ...XXXVI & YI & & 21,13 \\
\hline & e...XXXVII & & $\ldots V$ & $\ldots 13$ \\
\hline & ...LY & & $\ldots X$ & $\ldots 28$ \\
\hline & $3:, 37$ & & ...XXVIII & $\ldots 59$ \\
\hline & ...XII & & &. .30 \\
\hline & ...XLIII & & $\ldots \mathrm{X}$ & $\ldots 72$ \\
\hline & ...XXV & & $\ldots \mathrm{X}$ & $\ldots 43$ \\
\hline & $\ldots \mathrm{XL}$ & & ...XI & $\ldots 24$ \\
\hline [i] & 129 & tidæ & ...XLII & $\cdots 3$ \\
\hline
\end{tabular}




\section{PLATE II}

Family Type-Forms of Antennce in the first seclion, or Flies wilh many-jointed Antenna-NEMOCERA

$$
\text { |II.-CECIDOMYIDE }
$$

I. Epidosis longipes, $\delta$

2. Asphondylia sarothamni

$$
\text { III.-MYCETOPHILIDA }
$$

3. Sciara thomæ

4. Mycetophila cingulum

5. Mycetobia pallipes

6. Macrocera lutea

$$
\text { IV.-BIBIONIDA }
$$

7. Bibio marci, o

8. Scatopse notata

$$
\text { V.-SIMULID E }
$$

9. Simulium reptans

$$
\text { VI.-CHIRONOMIDÆ }
$$

10. Chironomus plumosus

II. Ceratopogon femoratus, $f$

12. Clunio marinus
IX.-CULICIDÆ

I3. Mochlonyx velutinus

I4. Corethra plumicornis, ?

XII.-LIMNOBID $Æ$

15. Limnophila dispar

16. Rhipidia maculata, t

I7. Erioptera flavescens

18. Trichocera hiemalis

XI.-PTYCHOPTERIDA

I9. Ptychoptera contaminata

XIII._TIPULIDA

20. Tipula gigantea

2I. Ctenophora pectinicornis

XIV.-RHYPHIDA

22. Rhyphos cinctus 


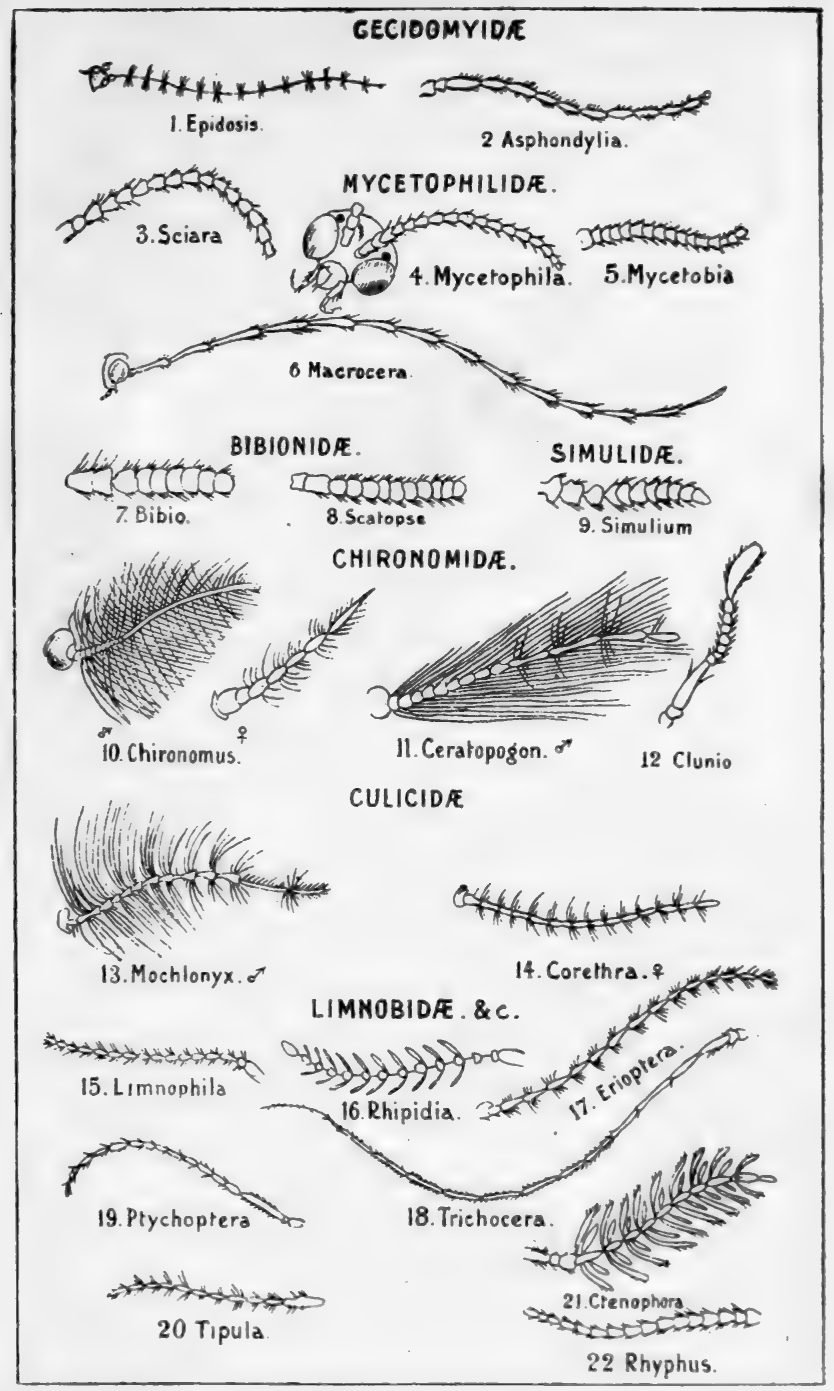

Plate II. (Appendix). 
Family Type-Forms of Antenna in lhe second section, or Flies with three or few-jointed Antenna

\section{XV.-STRATIOMYIDE}

I. Pachygaster atra

2. Oxycera pulchella

3. Stratiomys chamæleon

4. Sargus cuprarius

5. Beris chalybeata

6. Nemotelus uliginosus XVI.-TABANIDE

7. Chrysops cæcutiens

8. Hæmatopóta pluvialis

9. Tabanus bovinus XVII.-LEPTIDÆ

I0. Chrysopilus auratus

II. Leptis scolopacea

12. Atherix ibis

I3. Symphoromyia melaena

I4. Spania nigra XVIII.-ASILID $E$

I5. Leptogaster cylindrica

I6. Dioctria œlandica

I7. Isopogon brevirostris

18. Laphria marginata

19. Asilus crabroniformis XIX.-BOMBYLID $巴$

20. Anthrax hottentota

2I. Bombylius major XX.-THEREVID E

22. Thereva annulata XXI.-SCENOPINIDE

23. Scenopinus fenestralis XXIII.-EMPIDE

24a. Empis livida 24b. , borealis

25. Ardoptera irrorata

26. Ocydromia glabricula

27. Stilpon lunata 28a. Clinocera stagnalis 28b. " lota 29. Hybos grossipes 30. Tachista arrogans 3I. Chersodromia hirta 32. Cyrtoma spuria
XXIV.-DOLICHOPODIDA

33. Psilopus wiedemanni

34a. Dolichopus longicornis

34b. ", discifer

35. Chrysotus gramineus

36. Rhaphium longicorne

37. Medeterus diadema

XXV.-LONCHOPTERIDA

38. Lonchoptera lutea

XXVI.-PLATYPEZIDÆ

39. Platycnema pulicaria

40. Platypeza picta

XXVII.-PIPUNCULIDA

4I. Chalarus spurius

42. Pipunculus campestris XXVIII.-SYRPHIDÆ

43. Volucella bombylans

44. Xylota sylvarum

45. Orthoneura elegans

46. Chrysotoxum arcuatum XXIX-CONOPIDA;

47. Myopa buccata

48. Physocephala rufipes XXXI.-TACHINIDÆ

49. Zophomyia temula

50. Sarcophaga carnaria XXXII.-MUSCIDA

5I. Calliphora vomitoria XXXIV.-CORDYLURID压 52. Coniosternum obscurum 53. Scatophaga stercoraria

XXXVIII.-SCIOMYZIDÆ

54. Tetanocera ferruginea

LVI.-BORBORIDÆ

55. Borborus nitidus XXX-CESTRIDÆ

56. Hypoderma bovis LVII.-PHORIDÆ

57. Phora incrassata 


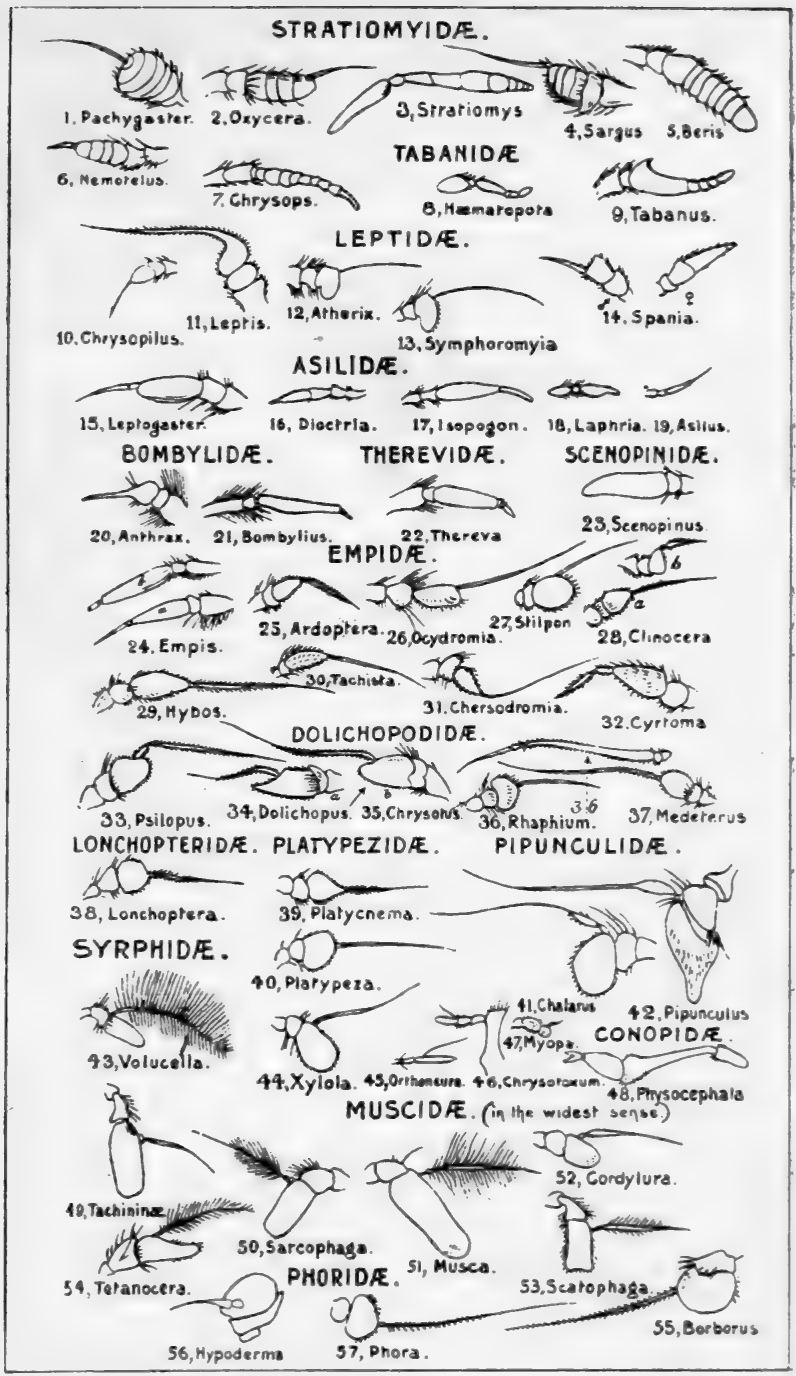

Plate III. (APPENDIX). 


\section{PLATE IV}

Family Type-Forms of the Wings of NEMOCERA

II.-CECIDOMYIDE

I. Cecidomyia rosaria

2. Lasioptera rubi

3. Catocha latipes

\section{III.-MYCETOPHILIDA}

4. Sciara thomæ

5. Mycetophila cingulum

6. Macrocera lutea

$$
\text { IV.-BIBIONIDA }
$$

7. Bibio pomonæ

$$
\text { V.-SIMULIDA }
$$

8. Simulium reptans

$$
\text { VI.-CHIRONOMIDE }
$$

9. Ceratopogon illustris

10. Chironomus plumosus

11. Tanypus monilis

$$
\text { VIII.-PSYCHODIDE }
$$

I2. Psychoda sexpunctata

$$
\text { IX.-CULICIDA }
$$

13. Culex annulatus

$$
\text { X.-DIXIDÆ }
$$

I4. Dixa maculata

$$
\text { XI.-PTYCHOPTERIDA }
$$

15. Ptychoptera contaminata

$$
\text { XIV.-RHYPHIDE }
$$

I6. Rhyphus cinctus

XII.-LIMNOBID $\Subset$

17. Dicranomyia stigmatica

18. Rhipida maculata

19. Symplecta punctipennis

20. Erioptera fuscipennis

21. Limnophila nemoralis

22. Trichocera hiemalis

$$
\text { XIII.-TIPULIDE }
$$

23. Nephrotoma dorsalis

24. Dolichopeza sylvicola 25. Pachyrrhina crocata 26. Tipula gigantea 


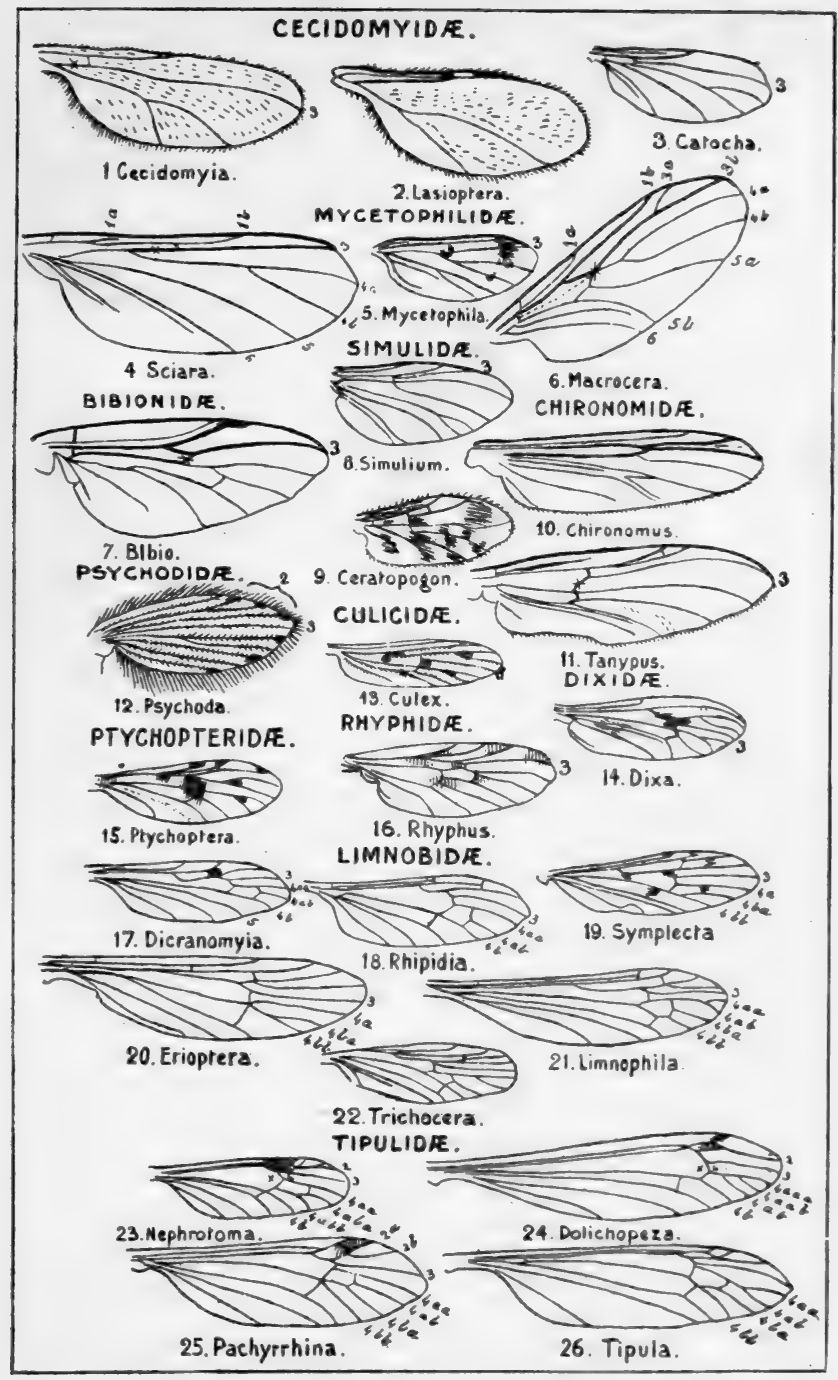

Plate IV. (APPEndix). 
Family Type-Forms of the Wings in the second section, or Flies with few-jointed Antenna

XV.-STRATIOMYIDE

I. Sargus cuprarius

XVI.-TABANIDA

2. Tabanus bovinus XVII.-LEPTID $巴$

3. Leptis scolopacea XVIII.-ASILIDE

4. Asilus crabroniformis

5. Isopogon brevircstris

XIX.-BOMBYLIDÆ

6. Bombylius major

7. Anthrax hottentota XX.-THEREVIDE

8. Thereva nobilitata XXI.-SCENOPINIDA

9. Scenopinus fenestralis XXIII.-EMPID尼

I0. Empis livida

II. Ocydromia glabricula

12. Stilpon lunata XXII.-CYRTIDÆ

13. Acrocera globulus XXIV.-DOLICHOPODIDE

I4. Dolichopus plumipes

15. Medeterus diadema

XXV.-LONCHOPTERIDA I6. Lonchoptera lutea, male. The dotted line shows V, 6 in the female.

XXVI.-PLATYPEZIDÆ

17. Platypeza picta

XXVII.-PIPUNCULIDA

I8. Verralia aucta

XXVIII.-SYRPHIDÆ

19. Syritta pipiens

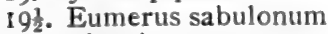

20. Eristalis tenax

21. Brachyopa bicolor
XXIX.-CONOPIDE

2I $\frac{1}{2}$. Physocephala rufipes

XXX.-CESTRIDAE

22. Gastrophilus equi

23. Oestrus ovis

XXXI.-TACHINIDÆ

24. Gymnosoma rotundatum

25. Cercomyia thoracica

26. Dexiosoma caninum

27. Sarcophaga carnaria

XXXII.-MUSCIDÆ

28. Calliphora erythrocephala

29. Mesembrina meridiana

XXXIII.-ANTHOMYIDE

30. Anthomyia pluvialis

XXXIV.--CORDYLURIDA

3I. Scatophaga stercoraria

XXXVIII.-SCIOMYZIDE

32. Tetanocera ferruginea

XXXIX.-PSILIDA

33. Psila fimentaria

XLII.-TRIPETIDE

34. Tephritis corniculata

LVII.-PHORID E

35. Phora rufipes

XL.-MICROPEZIDE

36. Micropeza corrigiolata

LI.-CHLOROPIDA

37. Centor cereris

LIV.-PHYT OMYZIDE 38. Chromatomyia affinis

LVI.-BOBORIDÆ

39. Limosina fontinalis

LVIII.-HIPPOBOSCID E 40. Hippobosca equina 


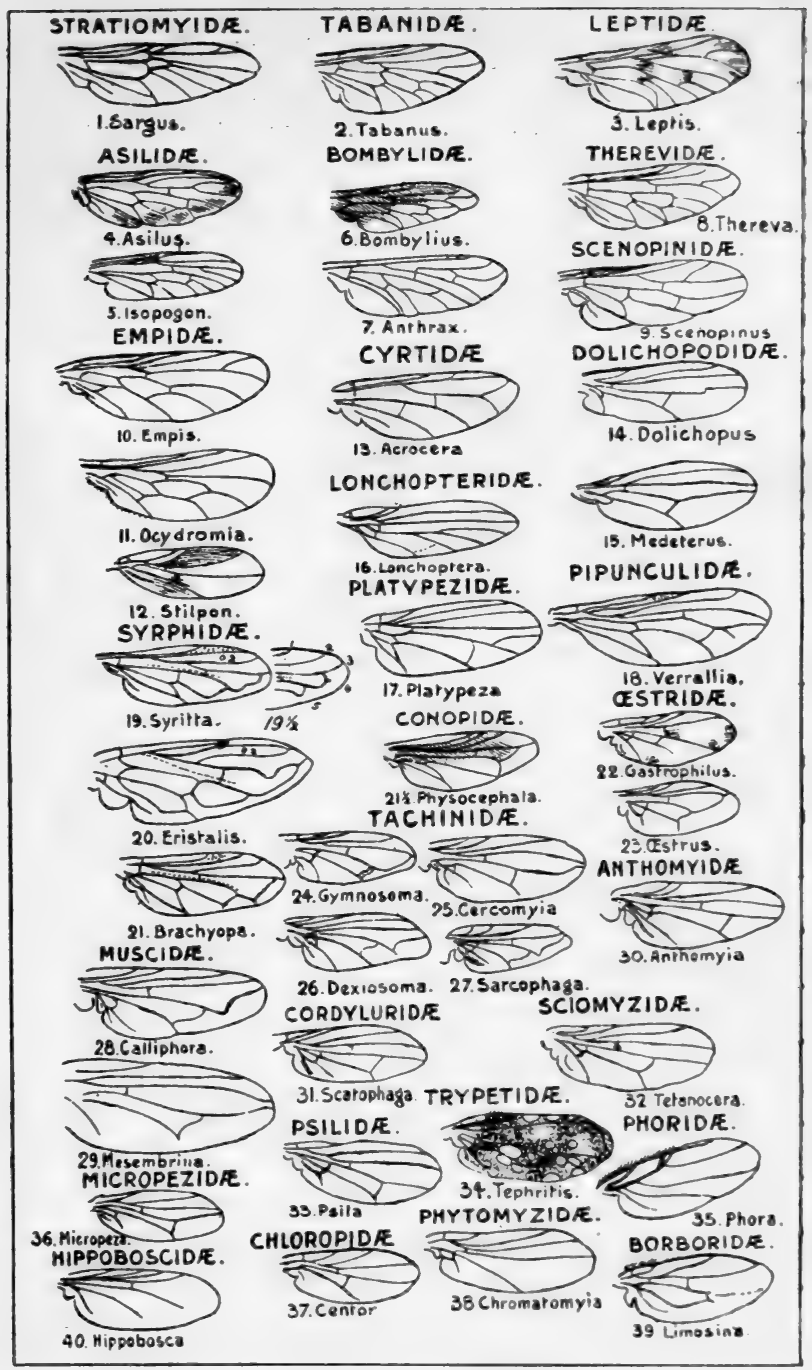

Plate V. (APPENDIX). 
I. Head of Mycetophila to show the position of the two ocelli.

2. Fore-leg of Dilophus

3.

4. Palpus of Limnobia

5. " Tipula

6. " Anopheles

7. , Culex

8. Foot of Dilophus

9. " Leptis

I0. " Asilus

II. " Thereva

12. Profile of Eumerus

I3.,$\quad$ Syritta

I4. $”$ Helophilus

I5. $” \quad$ Volucella

I6. " Rhingia

17. End of abdomen of Dolichopus

(a) the forceps

(b) the pennis

(c) the lamellæ

I8. Head of Psarus, viewed from above, showing frontal process

19. Shape of the proboscis in Empis

20. Shape of the proboscis in Hilara

21. Shape of the proboscis in Ocydromia

22. Shape of the proboscis in Euthyneura

23. Hind leg of Ramphomyia pennata

24. Hind leg of Sphœrocera subsultans

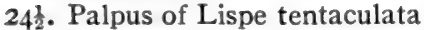

25. Leg of Limnophila-tibia spurred

26. Leg of Erioptera-tibia not spurred

27. Head and double-jointed proboscis of Myopa

28. Head of Asilus-front view (a) the hollowed vertex

(b) the mystax

29. Head of Drymia

30. Head and proboscis of Stomoxys calcitrans
31. Dorsum of Culex - no crossseam

32. Dorsum of Tipula-crossseams $(a-a)$, (disregarding characters other than crossseams)

33. Dorsum of Muscid (disregarding characters other than cross-seams)

34. Extremity of abdomen of Pedicia rivosa

35. Head of Stenopteryx sunk in shoulders

36. Foot and claws of Hippobosca

37. Puparium of Calliphora

38. T-shaped emergence-orifice in the pupa of Dixa-dorsal aspect

39. A mummy-pupa (Tipula)

40. Diagram of the Dorsum (I-I) Humeri or Shoulders

(2) Præ-sutural Central Region

(3) Post-sutural Central Region

(4-4) Post-humeral Region (5-5) Alar Regions

(6) The Scutellum

(7) The Neck

(8) Dorsal Suture

(9-9) Dorso-pleuralSutures

(I0-I0) Wing bases

(II-II) Scutellar Bridges

(12-I2) The Alar Frena

(I3-13) Inner rows of Dorso-central Bristles

(I4-I4) Outer rows of Dorso-central Bristles

(I5) The Scutellar Suture

4I, Diagramatic Chrtotaxy of

an Abdominal Segment

(I-I) Side Fore-marginal bristles

(2-2) Side Hind-marginal bristles

(3) Central Fore-marginal bristles

(4) Central Hind-marginal bristles

(5) Discal bristles 


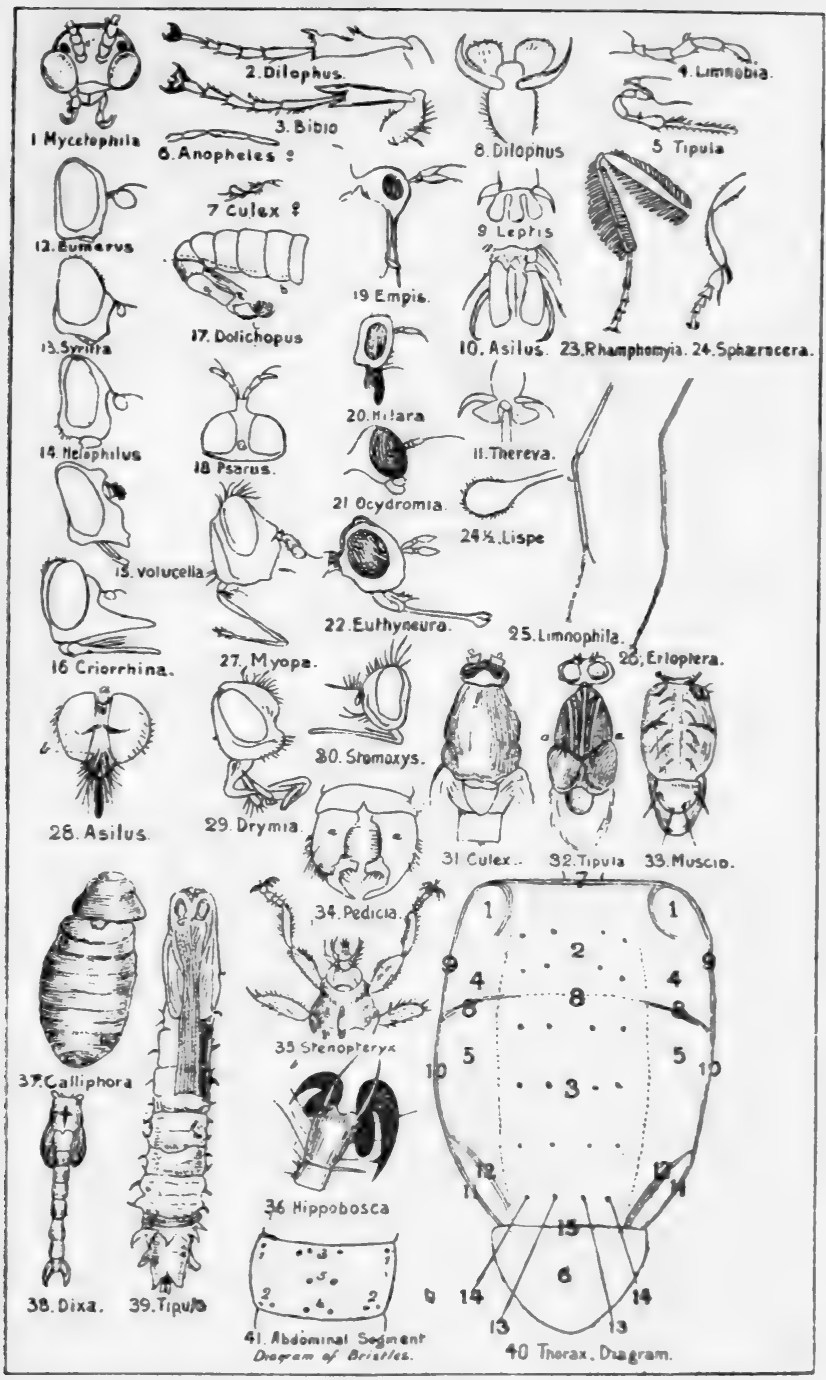

Plate VI. (APPENDIX). 


\section{PLATE VII}

I. Profile of Dorycera graminum

2. Profile of Trigonometopus frontalis

3. Profile of Platystoma seminationis

4. Profile of Ceroxys crassipennis

5. Head of Chilosia maculata $\delta$

6. Fore-leg of Platychirus manicatus, 8 ( 5 should be 6 ).

7. Fore-leg of Platychirus peltatus, 8

8. Fore-leg of Platychirus scutatus, ${ }^{\circ}$

9. Fore-leg of Platychirus albimanus, $\delta$

I0. Fore-leg of Platychirus clypeatus, $\delta$

II. Platychirus, $\delta$ and $q$, quadrate spotting

12. Melanostoma mellinum, ㅇ triangular spotting

13. Larva of Microdon

14. Wing of Helomyza pallida

I5 \& I6. Diagram of a fly's leg. Vide $\mathrm{C}$, I, on page $9 \mathrm{I}$.

15. As viewed from behind

I6. Asviewed, horizontal section

(through A-B)

(b.f.) base of femur

(t.f.) tip

(b.t.) base of tibia

(t.t.) tip

(I) upper or outer side

(2) under or inner ,

(3) hinder ",
(4) fore side

(5) upper fore side

(6) upper hind ,

(7) under hind ,"

(8) under fore "

I7 \& I8. Base of wing, illustrating the difference in $0,6^{1}$ respectively in

I7. Urophora

18. Trypeta

19. Profile of Drosophila

20. Profile of Ceratomyza denticornis

2I. Profile of Tichomyza fusca

22. Antennæ of Notophila cinerea; note the "thorn" on second joint

23. Antennæ of Hydrellia griseola

24. Antennæ of Tichomyza fusca

25. Profile of Hydrellia griseola

26. „ Ochthera mantis

27. Wing of Borborus equinus

28. , Limosina sylvatica

29. Section of a collector's net, showing

(a) the small end of a large net;

(b) a detachable muslin bag;

(c) elastic closing the bag;

(d) transparent celluloid end

30. A small bag, closed and detached

31. Box for carrying bags 


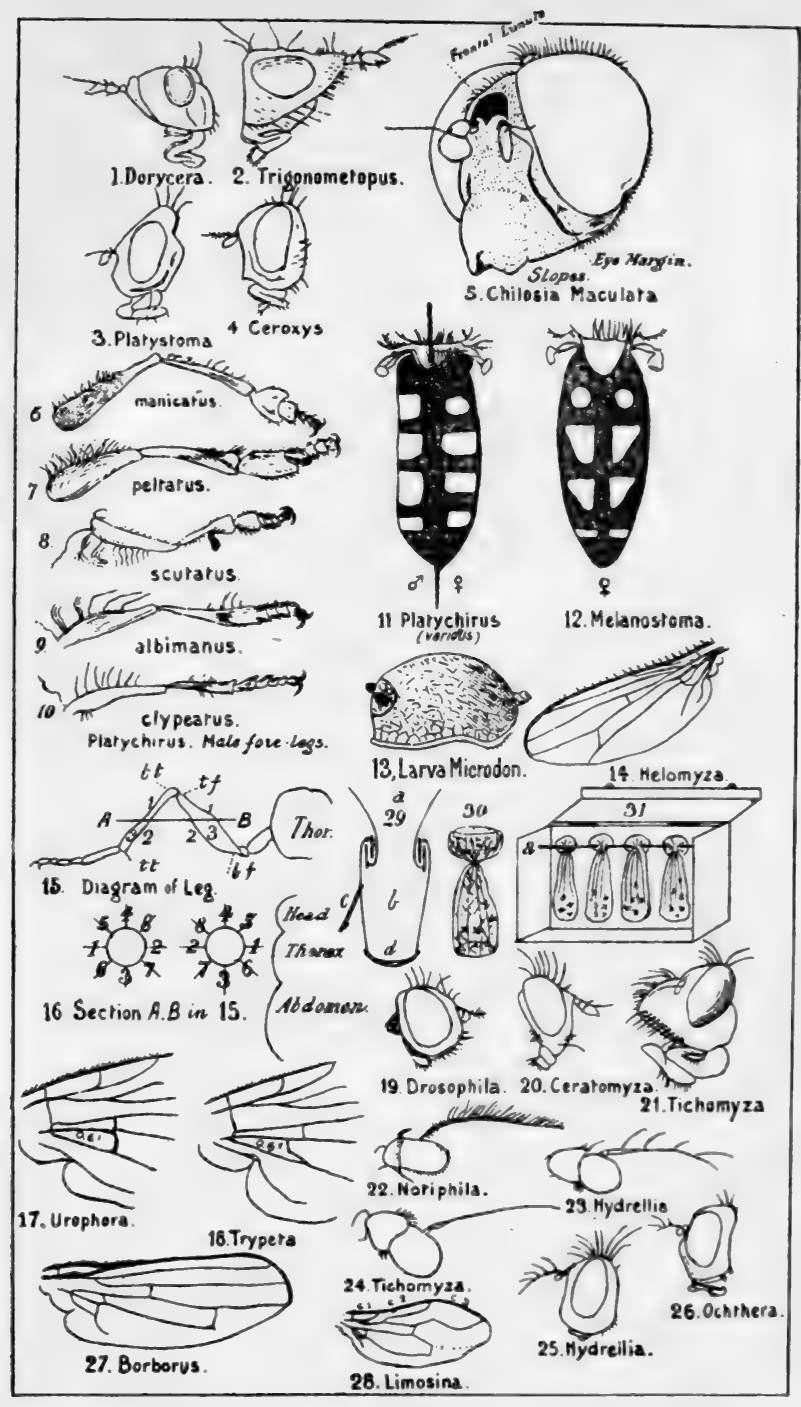

Plate VII. (APPEndiX). 


\section{NUMBERED LIST OF FAMILIES,}

Together with references to the Analytical Table and Notes.

The sequence of the numbering indicates some proximity of relationship, in most cases at least, in respect of some particulars.

Nos. Refs. FAMiLibs-Notes

I ... - PULICID : fleas regarded as flies with atrophied or undeveloped wings. About 30 native species.

II ... 3. CeCidonyide: mostly gall-gnats, minute and midge-like, or very frail, slender and gnat-like. Cecidomyia destructor is the notorious Hessian-fly, injurious to cereal crops.

III ... IO. MYCETOPHILID\& : fungus-gnats; 34 genera; many common species. The marvellous "army-worm," the larvæ of Sciara militaris, which (being not a feeder on fungi) may be classified either separately or as belonging to this family, has been observed travelling in Continental forests in millions, described as massed together with a viscous mucus in bands said to be as large as 5 or 6 inches wide, I inch deep, and 50 or more feet long!

IV.... II. BIBTONIDE: 40 species of small and medium sizes; commonly the males are black, but the females of some species coloured; Bibio marci, of a largish size, pubescent, and black, sometimes appears in great numbers on fine spring days, as likewise do some smaller black species of the same genus; ocelli absent; semi-blind.

V ... I3. SIMULID E: midge-like flies, mostly with wings, limbs, and bodies of short length; the largest, Simulitm reptans, only 2-3 mm., is common; its larvæ are aquatic. Some foreign species are called sand-flies and are much dreaded poisonous blood-suckers.

VI ... I4. CHIRONOMIDE: midges and many small, slender and gnatlike flies; Ceratopogon pulicaris, C. bipunctatus, and C. varius are our commoner native blood-sucking midges, of which the larvæ have been found under the damp bark of decadent trees; the larvæ of some others are aquatic, as also are all those of the long slender non-blood-sucking species, including those of the very common harlequin-fly, Chironomus plumosus, as also of several congerers, including $\mathrm{Ch}$. dorsalis, of which the larvæ are known as "pond blood-worms." 
Nos. Refs. FAMILIES-Notes

VII ... I9 $b$. ORPHNE PHILIDE (darkness-loving): all foreign flies, except one rare.

VIII ... I6. PSYCHODIDE : minute moth-like flies; they have been named owl-midges from a peculiar manner of holding their wings in repose.

IX ... 18. CULICIDE: the true gnats or mosquitoes; 5 genera, I8 native species; three common, including Culex pipiens; larvæ abundant about marshy land and everywhere in water from which fish are absent, even in brackish water, but particularly in the stagnant water of small pools and vessels.

X ... I9a. DIXIDE : a few small and gnat-like flies; larvæ aquatic.

XI ... 2I. PTYCHOPTERIDE: larvæ in shallow muddy pools.

XII ... 23. LimNOBIDE: 32 genera and more than 100 species; generally marsh and fen slender flies, large and small, rather resembling "crane-flies"; the larvæ live some in decaying vegetable matter, some in fungi, some are aquatic, and some are unknown; two species called "winter-gnats," genus Trichocera, are very common.

XIII ... 24. TIPULID E : true crane-flies or daddy-long-legs; about 60 species; larvæ (leather-jackets) underground in turf, or in decadent matter.

XIV ... 8. RHYPHID size; larvæ in rotting vegetable matter.

XV ... 28. STRATIOMYIDE: I2 genera, 40 or more species; proboscis imperfect; wings rather small in comparison with the body, which is free from hairiness; a few are those large and conspicuously bright-coloured flies, which are called "soldierflies"; the larvæ of the genus Strationy's are known as "startailed" maggots.

XVI ... 30. TABANIDE: breeze-flies: ocelli absent; the short welldeveloped proboscis of the blood-sucking female pierces the skin of mammalia; the abdomen is somewhat pubescent, never hairy ; semi-blind; larvæ in damp earth, predaceous.

XVII ... 3I, 37. LEPTIDE; a family of few species resembling some Empidær rather than the flies of any preceding family. Lcptis scolopacca is a large fly, common in meadows, yellowish body with black spots.

XVIII ... 40. AsILIDE: the "robber-flies," which are more boldly voracious than any other raptorial flies, preying on winged insects, large and small; terrestial predaceous larvæ.

XIX ... 42. BOMBYLID $\mathrm{E}$ : furry, hovering, bee-like flies, mostly very long-tongued; bodies very rotund but with legs singularly thin; larvæ, some parasitic on the larvæ of ground bees, some unknown. 
Nos. Refs. FAMILIES-Notes

XX ... 43. THEREVIDE: non-raptorial flies; smaller, shorter, and more feeble than Asilidæ; though differing much in wingpattern superficially like some Leptidæ or some Empidæ.

XXI ... 44. SCENOPINIDE: a very limited family of smallish flies. Scenopinus fencstralis, the "window-fly" was formerly thought to breed amidst old carpets and musty neglected clothing, but its larvæ have been found to be therein predaceous devourers of the larvæ of clothes-moths and fleas; larvæ of other species feed on fungi.

XXII ... 38. CYRTIDA : quite unlike any of the preceeding or succeeding families; flies with diminutive heads and large rotund abdomens; proboscis very short or obsolete; the larvæ of some are said to be parasitic on spiders.

XXIII ... 45, 49, 66a. EMPID $£$ : an extensive family; about 200 species, mostly of small sizes; of slender habit, and of dull colours; there are 30 genera and the characteristics of some are peculiar; the life-history and habits of most are unrecorded; though with bodies of feeble appearance, some have the proboscis well devolped and are predaceous on small insects. Amongst the most curious are some species of the genus Hilara, of which the males have the first tarsal joint of the fore-leg thickened and flattened; some species of this genus, not very uncommon, fly and float about carrying "veils" or small cob-web-like attachments.

XXIV ... 50, 65. DOLICHOPODIDE: : long-legged; a large family of $\mathbf{4 2}$ genera; some species of medium size but mostly small, amongst which latter bright metallic colours, often golden green, are common. The life-history of only a few is known.

$\mathrm{XXV}$... 51. LONCHOPTERIDE: a few small slender flies with long pointed wings.

XXVI ... 53. PlatyPEZIDE: small flies; the peculiar broad flat larvæ of some of the genus Platypeza have been found in fungi.

XXVII ... 58. PIPUNCULIDE: small and uncommon filies with abnormally large eyes

XXVIII ... 59. SYRPHIDE: a most interesting group of 51 genera; "hover-flies," and other various, conspicuous, large and medium sized flies (only a few small), very distinctly characterised and differentiated; the wings show the "vena spuria," and the face is without a "frontal suture." The larvæ are very diversified; some are terrestrial, some aquatic, some insectivorous, some parasitic or commensal in the nests of Hymenoptera.

XXIX ... 54, 60. CONOPID E: the wings show no "vena spuria"; the known larvæ are parasitic on Hymenoptera and Orthoptera. 
Nos Refs. FAMILIES-Notes

XXX ... 62. OESTRID $Æ$ : a few very distinct species; proboscis and mouth parts atrophied; very hairy except one very rare; parasites of mammalia.

XXXI ... 72. TACHINIDE: IOO genera, more than 250 native species; with great difficulty classed in divisions, which may rank as separate families; stoutness of body and abundance of strong hairs, or rather brislles, are so generally apparent that many species may be guessed to belong to this family rather than to the closely related Muscidæ. Many of the larvæ are parasitic on various insects.

XXXII ... 73. MUSCIDÆ: I5 genera, comprising 36 native species, mostly very common, and many superabundant throughout summer by reason of rapid breeding.

XXXIII ... 74. ANTHOMYIDÆ: 4 sub-families (MydÆInÆ, ANTHO-

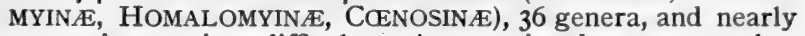
300 native species; difficult to characterise, but many rather resemble the lesser house-fly in size, and more or less in appearance, habit, and life-history, but some seem attracted rather more to flowers and others drawn only towards dung. XXXIV ... 82. CORDYLURIDA: 29 genera; absence of squamæ apparent; otherwise generic features and general sizes and bodily shapes of species vary considerably. The yellow cowdung fly, Scatophaga stercoraria, is the commonest species of this large family.

XXXV ... 89, II6. PhyCODRomidÆ: sea-shore flies.

XXXVI ... 80. HELOMYZIDA : 8 genera; the costa of wings very "pectinate"; wings large and abdomen small.

XXXVII ... 78. HETERONEURID : 3 native species; smallish elongated wings; the larvæ, which live in rotten wood, can jump, somewhat like the cheese-hopper maggots.

XXXVIII ... 86, 95. SCIOMYZID E: II genera; slender flies with tinted brownish wings; larvæ aquatic.

XXXIX ... IOI, I35. PSILIDÆ: 4 genera.

XL ... I03, I09. MICROPEZIDE: 6 native species.

XLI ... 87, I04. ORTALIDÆ : about 20 species; smallish flies; some common in pastures; legs short and stout.

XLII ... 97. TRIPETIDÆ: numerous small species; larvæ in stems of plants, or galls thereon, some leaf-miners.

XLIII ... 92. LONCHÆID E: some are of a plump figure and a dark metallic blue or green, others more slender and yellow, grey, or black.

XLIV ... 93. SAPROMYZIDE: 21 species.

XLV ... I39. OPOMYZIDÆ: 5 species; life-history unknown.

XLVI ... 83, I02, I2I, I36. SEPSID E: several are common small dung-flies, with black bodies, somewhat ant-like. 
Nos. Refs. FAMILIES-Notes

XLVII ... I20. PIOPHILIDE: the "cheese-hopper" maggots are larvæ of Piophila casei; seven other species.

XLVIII ... 132. GEOMYZID E : I2 species.',

XLIX ... II3. EPHYDRIDE : nearly I00 species; life-history of few known.

L ... II4, I3I. DROSOPHILIDE: larva leaf-miners. The pale yellow "fruit-fly," Drosophila fenestrarum, loves the ciderpress and fermenting fruit.

LI ... III. CHLOROPID E : numerous family; in the genus Chlorops are many beautiful little flies.

LII ... I29. MICHILIDE: 2 native species.

LIII ... I27, I38, AGROMYZIDE: some are leaf-miners.

LIV ... 68, I25. РнутомуZID : leaf-miners.

LV ... I26. AsTIADÆ: 2 species; life-history unknown.

LVI ... I06. BORBORIDE: first tarsal joint $(C, I, 5)$ of hind leg conspicuously thick and short; small species of the genera Borborus and Sphcrocera often abound in the dung-pits of mews. The larvæ of some have been found on rotting potatoes and on confervæ.

LVII ... I40. PHORIDE: a numerous family of small flies; 6 genera.

LVIII ... I44. HIPPOBOSCIDE: the females of some shed their wings, and all live a lice-like life attached to animals.

LIX ... I43. BRAULIDE: eyeless and with strangely atrophied body appendages; found in bee-hives.

LX ... I45. NYCTERIBID $Æ$ : wingless parasites on bats; with small heads held in a curious posture. 


\section{ANALYTICAL TABLE OF FAMILIES}

\section{ORDER-DiPTERA}

I (I4I). Insects with the head distinct from the thorax, with one pair of wings, one pair of halteres, 5-jointed tarsi, proboscis not spirally coiled; with a well defined pupal stage intermediate between the larval stage and the perfect insect.

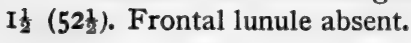

SUB-ORDER I. ORTHORRHAPHA (comprising 25 families); flies with "mummy-pupæ," see plate VI, figs. 38 and 39.

2 (25). Antennæ many-jointed (plate II).

NEMATOCERA (thread-horns)-

3 (4). Vein endings round the margin (plate IV, figs. I, 2, 3) not more than 6 .

CECIDOMYIDE, II

4 (3). Vein endings more than 6.

5 (20). Thorax (plate VI, 3I) without B, I, 8 conspicuous.

6 (I5). Costa ending at apex of wing (plate IV, 4-II).

7 (I2). Ocelli as in plate I, or as in plates VI, I and II, 4.

8 (9). Discal cell $\left(\mathrm{O}, 4^{b}\right.$ or $\left.\mathrm{O}, 5^{2}\right)$ present (platc IV, I6).

RHYPHID E, XIV

9 (8). Discal cell absent (plate IV, 4-7).

IO (II). Antennæ long (plate II, 3-6) ; or, if short, coxæ elongated.

MYCETOPHILID $E$, III

II (I0). Antennæ as in plate II, 7 and 8 ; coxæ not elongated.

12 (7). Ocelli absent.

\section{BIBIONID E, IV}

I3 (I4). Antennæ (plate II, 9) shorter than B; wings (plate IV, 9) broad.

SIMULIDA, V

I4 (13). Antennæ (plate II, I0, II) longer; wings narrow (plate IV 9-II).

CHIRONOMIDE, VI

I5 (6). Costa (plate IV, I2-I4) around hind margin.

I6 (I7). Wings held roof-like, hairy; $\mathrm{X}$ only at base (platc IV, I2). 
PSYCHODIDE, VIII

I7 (16). Wings flat over $\mathrm{D}$; $\mathrm{X}$ on middle of wing.

I8 (19). Veins hairy (plate IV, I3).

I9 (18). Veins bare.

\section{CULICIDE, IX}

I $9 a($ I $9 b)$. Antennæ long; V, 4 and V, 2 forked; X, 4 (plate IV, I4) ending in $\mathrm{V}, 2$.

\section{DIXIDE, $\mathrm{X}$}

I9b (I9a). Antennæ very short but II-jointed; no veins forked.

ORPHNEPHILIDE, VII

20 (5). Thorax (plate VI, 32) with a strong cross seam.

2I (22). V, 6 absent (plate IV, I5).

22 (2I). V, 6 present.

\section{PTYCHOPTERIDÆ, XI}

23 (24). V, I $a$ ending in costa and (plate IV, I7-22) united to V, I $b$ by $\mathbf{X}, \mathbf{I} b$; last joint of palpi (plate $\mathrm{VI}, 4$ ) never whip-like.

\section{LIMNOBIDE, XII}

24 (23). V, I $a$ ending in V, I $b$; and, except for X, I $a$ at its base, not united by X (plate IV, 23-26); palpi (plate VI, 5).

\section{TIPULIDÆ, XIII}

25 (2). Antennæ short, 3-jointed (plate III) ; 3rd joint sometimes ringed.

BRACHYCERA (short-horns)-

26 (I40). Wing veining normal; X-veins present.

27 (32). Third antennal joint ringed; A, IV, 6, if present (plate III, I-9) apical.

28 (29). Costa ending at apex of wing (plate V, I).

\section{STRATIOMYIDE, XV}

29 (28). Costa around the hind margin (plate $\mathrm{V}, 2$ ).

30 (3I). Squamæ very large.

3I (30). Squamæ very small.

$$
\text { TABANIDE, XVI }
$$

\section{Part of LEPTIDE, XVII (genus Xylophagus)}

32 (27). Third joint of antennæ (plate III, I0-55) not ringed.

33 (55). Arista terminal or wanting (plate III, 10-26, 28-32, 35-40, 48)

34 (46). V, 3 forked (plate V, 3-10, 13).

35 (45). O, 61 long, extending (or nearly) to hind margin, or entirely wanting (plate $\mathrm{V}, 3-9, \mathrm{I} 3$ ). 
36 (39). C, I, (1I) much enlarged, appearance of 3 foot-pads (plate VI, 9).

37 (38). Squamæ small, not covering C. III ; O, $6^{1}$ long and distinct (plate $\mathrm{V}, 3$ ) ; long bodied flies, head of normal proportions.

\section{Part of LEPTIDE, XVII}

38 (37). Squamæ very large, hiding the halteres; $O, 6^{\mathrm{I}}$ absent (plate $\mathrm{V}, \mathrm{I} 3$ ) ; short round-bodied flies with very small heads.

CYRTIDÆ, XXII

39 (36). Empodium small, only 2 foot-pads apparent (plate VI, I0, II).

40 (4I). Vertex hollowed out between the eyes (plate VI, 28).

\section{ASILIDE, XVIII.}

4I (40). Vertex flat or raised, eyes not protruding.

42 (43) (44). V, 4 ending in 3 branches (plate $\mathrm{V}, 6,7$ ) between $\mathrm{V}, 3$ and $\mathrm{V}, \mathbf{5}$.

\section{BOMBYLIDÆ, XIX}

43 (42) (44). V, 4 ending in 4 branches (plate $\mathrm{V}, 8$ ) between $\mathrm{V}, 3$ and $\mathrm{V}, 5$.

THEREVIDE, XX

44 (42) (43). V, 4 ending in 2 branches (plate V, 9) ; antennæ (plate III, 23) without A, IV, 6.

\section{SCENOPINIDE, XXI}

45 (35). $\mathrm{O}, 6^{1}$ short (plate $\mathrm{V}, 10$ ) not nearly reaching hind margin. Part of EMPIDE. XXIII

46 (34). V, 3 not forked (plate V, II-I2, I4-I7).

47 (52). Alulæ absent or rudimentary.

48 (5I). Apex of the wing rounded.

49 (50). X, 4 placed generally beyond $X, 5^{1}$, at most only a little before it; V, 5 with $2 \mathrm{X}$-veins bounding a discal cell (plate V, II) ; or, if only one, then X, 5 is placed before, or, at most (plate $\mathrm{V}, \mathrm{I} 2$ ) only a little beyond $\mathrm{X}, 4$.

\section{Part of EMPIDE, XXIII}

50 (49). $X, 4$ placed very near the base of the wing; V, 5 with only one $\mathrm{X}$-vein placed far beyond $\mathrm{X}, 4$; no discal cell (plate $\mathrm{V}$, I4, I5).

Part of DOLICHOPODIDE, XXIV

5I (48). Apex of the wing (plate $\mathrm{V}, \mathrm{I6}$ ) pointed.

LONCHOPTERIDÆ, XXV

52 (47). Alulæ present.

$52 \frac{1}{2}$ (I $\frac{1}{2}$ ). Frontal lunule (plate VII, 5) present.

SUB-ORDER II. CYCLORRHAPHA (families XXVI-LX); flies which escape from a puparium, formed of the indurated larval skin, through a circular orifice made by pushing off its head end (plate VI, 37). 


\section{PROBOSCIDEA}

53 (54). Antennæ (plate III, 39, 40) with a long seta or bristle

\section{PlatyPEZIDE, XXVI}

54 (53). Antennæ (plate III, 48) with a short seta or spine

$$
\text { Part of CONOPIDE, XXIX }
$$

55 (33). Arista dorsal (plate III, 27, 33, 34, 41-47, 49-55).

56 (6I). O, $6^{1}$ long (plate V. I8-2I $\frac{1}{2}$ ) extending nearly to hind margin : D without strong bristles (macrochætæ).

57 (60). Proboscis of moderate length (plate VI, 12-16) generally retracted.

58 (59). Vena spuria (plate $\mathrm{V}, \mathrm{I} 8$ ) absent ; A, II very large; $\mathrm{O}, 4^{2}$ open.

\section{PIPUNCULIDE, XXVII}

59 (58). Vena spuria present (plate V, I9-2I); O, $4^{2}$ c closed ; A, II moderate.

\section{SYRPHIDE, XXVIII}

60 (57). Proboscis projecting far in front, very thin and long, often double-kneed (plate VI, 27); no vena spuria (plate V, 2I $\frac{1}{2}$ ).

\section{Part of CONOPIDE, XXIX}

$6 \mathrm{I}(56) . \mathrm{O}, 6^{1}$ short, not nearly reaching margin, or absent (plate $\mathrm{V}$, 12, 22-39) abdomen often with strong bristles.

62 (63). Proboscis and palpi atrophied.

\section{CESTRIDE, XXX}

63 (62). A, VIII, 3 and 4 distinctly present.

64 (67). X, $5^{1}$ absent, $X 5^{2}$ present, i.e., only one.X-vein on V, 5 and that beyond $\mathrm{X}, 4$.

65 (66). X, 4 very near base of wing (plate V, I4, I5); X, 5 far beyond $\mathrm{X}, 4$.

\section{Part of DOLICHOPODIDÆ, XXIV}

66 (65). X, 4 more towards middle of wing (platc V, I2, 36, 37) nearer X, 5 .

$66 a(66 b)$. Proboscis directed straight downwards.

$$
\text { Part of EMPIDÆ, XXIII (genus Stilpon) }
$$

$66 b(66 a)$. A, VIII, 3 retracted [ordinary Muscid type] pass on to 108 of this table.

67 (64). X, $5^{1}$ present, that is, a X-vein on V, 5 before, or under $\mathrm{X}, 4$; or no X-veins on V, 5 .

68 (69). No X-veins on V, 5.

\section{Part of PHyTOMYZIDE, LIV}

69 (68). At least $X, 5^{1}$ present, generally also $X, 5^{2}$.

70 (75), Squamæ distinctly present though sometimes small. 


\section{- MUSCIDE CALYPTERA -}

$7 I$ (74). V, 4 angled or bent towards V, 3 (plate V, 24-29).

72 (73). D with $E$ (macrochætæ and hairs) on middle segments; otherwise A, IV, 6 is bare or bare on the tip-half (plate III, 49-50).

\section{TACHINID $E$, XXXI}

73 (72). D without macrochætæ though often with rather strong hairs; A, IV, 6 fully plumed or combed (plate III, 5I).

\section{MUSCIDE, XXXII}

74 (7I). V, 4 going straight or nearly straight to margin (plate $\mathrm{V}, 30$ ).

\section{ANTHOMYIDE, XXXIII}

75 (70). Squamæ absent or rudimentary.

\section{- MUSCIDA ACALYPTERE -}

76 (105). V, I $a$ distinctly present, nearly as thick as V, I $b$, which generally ends in the fore margin at or beyond the middle of the wing (plate $\mathrm{V}, 3 \mathrm{I}, 32,34$ ).

77 (84). Vibrissæ present (plate VIII, 2) together with more or less hair.

78 (79), V, $4^{4}$ four or five times as long as $\mathrm{V}, 4^{3}$ (i.c., $\mathrm{X}, 5^{2}$ nearer $\mathrm{X}^{4}$ than to wing margin).

\section{HETERONEURIDE, XXXVII}

79 (78). V, $4^{4}$ about equal to $\mathrm{V}, 4^{3}$, or only a little longer.

80 (8I). Costa with spines in addition to the ciliation (platc VII, I4).

\section{HELOMYZID止, XXXVI}

8I (80). Costa without a row of spines, only ciliated.

82 (83). A, III (5) present, or, if absent, then body never shining black.

\section{CORDYLURIDE, XXXIV}

83 (82). Fronto-orbital bristles absent; body always shining black.

$$
\text { Part of SEPSID E, XLVI }
$$

84 (77). Vibrissæ absent; mouth with short hairs or bare (plate VII, $I, 3,4)$; or, if the hairs are strong, all of same length and strength.

85 (88). A, IV very long and horizontal ; A, IV (4) as long or longer than A, IV (5) of which the upper edge is concave (plates III, 54 ; VII, I).

$86(87)$. Profile not triangular; face perpendicular or slightly retreating.

\section{Part of SCIOMYZIDE, XXXVIII}

87 (86). Profile triangular; A, V retreating (plate VII, I) almost horizontally. 


\section{Part of ORTALIDE, XLI}

88 (85). Antennæ not long, or. if long, drooping; A, IV (4) shorter than A, IV (5) of which the upper edge is straight or convex.

89 (90). Brown or black shore flies with flat horny thorax and with strong mouth hairs.

\section{Part of PHyCODROMIDE, XXXV}

90 (89). Otherwise than 89.

$9 \mathrm{I}(94) . O, 5^{1}$ and $O, 6^{1}$ very small and indistinct.

92 (93). Only one fronto-orbital bristle on each side ; tibiæall without the præ-apical bristle.

\section{LONCHÆIDE, XLIII}

93 (92). A, III (5) on each side; the præ-apical E on some of the C, I (4).

\section{SAPROMYZIDE, XLIV}

94 (9I). O, $5^{1}$ and $O, 6^{1}$ fairly large and quite distinct.

95 (96). Hind tibiæ with a præ-apical bristle.

\section{Part of SCIOMYZIDE, XXXVIII}

96 (95). Hind tibiæ without the præ-apical bristle.

97 (98). A, III (6) present and close to A, II ; V, I $a$ isharply bent up at its end (plate $\mathrm{V}, 34)$. Wings usually spotted ; ovipositor protruding.

\section{TRYPETIDE, XLII}

98 (97). Lower fronto-orbital bristles absent ; V, I $a$ gently bent up. 99 (104). Legs long; abdomen narrow and long, contracted at base. I00 (I03). V, 4 straight or nearly so. Shining black species.

IOI (I02). V, 6 reaching to the wing margin; abdomen narrow, more than twice as long as the thorax.

\section{Part of PSILIDE, XXXIX}

102 (IOI). V, 6 not nearly reaching margin; $\mathrm{D}$ rather broad.

\section{Part of SEPSIDE, XLVI}

I03 (100). V, 4 much bent towards V, 3. Brown species.

$$
\text { Part of MicropezIDE, XL (genus Calobata) }
$$

104 (99). Legs normal; D comparatively short and broad, never contracted at base.

$$
\text { Part of ORTALIDE, XLI }
$$

I05 (76). V, I $a$ absent or rudimentary, much thinner than $\mathrm{V}, \mathbf{I} b$, which latter ends at or before the middle of the fore margin. 106 (107). Hind C, I (5) thickened and shorter than the next joint.

$$
\text { BORBORIDA, LVI }
$$

107 (I06). Hind metatarsus longer than and not thicker than $C, I(6)$. 
$\mathrm{I} 08$ (II5). X. $5^{1}$ absent, X, $5^{2}$ present (i.e. only one X-vein on V, 5 and that placed beyond $\mathrm{X}, 4$ (plate $\mathrm{V}, 36$ ).

109 (II0). Legs long and thin ; abdomen very long.

Part of Micropezide, XL (genus Micropeza)

II0 (109). Legs short and strong; D oval or elliptical.

III (II2). A, III (6) absent ; A. IV (5) round, or, if lengthened, then $A$ in profile is triangular.

\section{CHLOROPIDE, LI}

II2 (III). A, III (6) present ; A, IV (5) generally long or oval ; A in profile never triangular.

II3 (II4). Head square; face strongly convex (platc VII, 2I); O, 61 absent. Not orange coloured species.

EPHYDRIDA, XLIX

II4 (II3). Head round or semi-circular; face not arched (plate VII, 19) ; $O, 61$ present, or, if absent, then the species orange coloured.

\section{Part of DROSOPHILIDE, L.}

II 5 (I08). X, $5^{1}$ present, or, if absent, then $\mathrm{X}, 5^{2}$ also absent (i.e., either two X-veins or no X-veins on V, 5 ) (plate $\mathrm{V}, 33,38$ ).

II6 (II7). Scutellum of the male extraordinarily long and squared off behind ; costa thickened from the end of V, I to the wing tip.

\section{Part of PHycoDROMIDE (genus Thyreophora)}

II7 (II6). B, I (6) usually short, and somewhat triangular; costa normal.

II8 (I33). Mouth bristles present.

II9 (I22). Fronto-orbital bristles absent.

120 (I2I). Wings without a black spot near the tip.

PIOPHILIDE, XLVII

I2I (I20). Wings with a black spot near the tip.

\section{Part of SEPSIDE, XLVI}

122 (II9). Fronto-orbital bristles present.

123 (128). $X, 5^{2}$ before middle of wing (both $X, 4$ and $X, 5^{2}$ near the base and exceedingly near together) or no $X$-vein on $V, 5$.

I24 (127). X, $5^{2}$ immediately under $X, 4$ (or nearer the base), or $\mathrm{X}, 5^{1}$ and $\mathrm{X}, 5^{2}$ both absent (plate $\mathrm{V}, 3^{8}$ ).

125 (126). Arista bare or nearly so.

$$
\text { Part of PHYTOMYZIDE, LIV }
$$

126 (125). Arista with long hairs on one side. 


\section{AstLADE, LV}

I27 (I24). X, $5^{2}$ present and placed further from base than X, 4 .

\section{Part of AGROMYZIDE, LIII}

I 28 (123). $X, 5^{2}$ at or beyond the middle; X, 4 and $\mathrm{X}, 5^{2}$ neither very near to the wing base nor to one another.

I29 (I30). Arista bare ; body short and broad.

\section{MILICHIDE, LII}

I30 (I29). Arista plumose, combed, or pubescent, or, if bare, then the body always narrow and long.

I3I (I32). Arista thinly but long haired, plumose, or combed.

$$
\text { Part of DROSOPHILIDE, L }
$$

I32 (I3I). Arista thickly and short haired, pubescent, or bare.

\section{GEOMYZIDE, XLVIII}

133 (I I8). Mouth bristles absent.

134 (I37). O, $5^{1}$ and $\mathrm{O}, 6^{1}$ large and very prominent.

I35 (136). Antennæ moderately long or very long, male genitalia not prominent.

\section{Part of PSILIDE, XXXIX}

136 (135). Antennæ short; male genitalia prominent, and clubshaped.

Part of SEPSIDE, XLVI (genus Tetanura)

I37 (134). O, 51 and $O, 61$ small and not very prominent.

I38 (I39). Light grey or silvery species.

$$
\text { Part of AGROMYZIDÆ, LIII }
$$

I39 (I38). Orange or brownish-red species.

\section{Part of OPOMYZIDE, XLV}

I40 (26). Wings with two short very thick veins (in fore-basal region) whence spring a few very fine unbranched veins. $\mathrm{X}^{-}$ veins absent (plate $\mathrm{V}, 35$ ).

\section{PHORIDE, LVII}

I4I (I) (523). Body of a horny or leathery nature; head sunk into a hollow in the thorax (plate VI, 35). No proper proboscis or palpi; claws very large (plate VI, 36). Perfect insect parasitic.

\section{EPROBOSCIDEA-}

I 42 (I45). Head fairly large; wings sometimes shed or absent.

I 43 (I44). Eyes, ocelli, scutellum, halteres, and wings all absent; last tarsal joint combed with bristles. 
BRAULIDE, LIX

I44 (I43). Eyes and scutellum present; last tarsal joint with well developed claws.

HIPPOBOSCIDÆ LVIII

I45 (I42). Head small, when at rest thrown back upon the dorsum ; always wingless.

NYCTERIBIDE, LX 


\section{INDEX}

Air-sacks, breathing by, 46

ANTHOMYIDA, 10, I7

Asilus crabroniformes, 55

Aphides, plant-lice, etc., 8

Beelzebub, Lord-of-flies, 2

BIBIONIDE, semi-blindness of, 108

Birds, food for, 80

Black death, 2

Blood-sucking flies, kinds of genus, chrysops, 24

" haematobia, $\mathbf{1 6}$

" hamalopota, 23

" lyperosia, I7

" tabanus, 23

" therioplectes, 23

Blood-sucking midges and gnats

- common species -

ceratopogon pulicaris, 108

" bipunctatus, 108

" varius, 108

(also others of the same genus and of the allied genus, anopheles

culex pipic $n$ s, 108

Blue-bottles, I2, I8, 33, 36, 5 I

Borborus cquimus, 34

Bot-fly of the horse, 26

Breeze-flies, “blinden," I0, 23, 29, 69

Bridgewater Treatises, I

Cabbage-fly, I7

Calliphora crythroccphala $\begin{gathered}\text { see } \\ \text { blue- } \\ \text { bottles }\end{gathered}$

Celery-fly, 17

$$
\text { vomitoria }\} \text { blue- }
$$

Chelifers, 55

Chry'sops crecuticns, 24

relicta 24

Conops flavipes, 22

Contagion, fly-borne, 84
CORDYLURIDA, IO

Cow-dung fly, the yellow, I9

Crane-flies, or Daddy-long-legs, 109

Cremation of refuse, 4I, 6I, 65, 70

Cyrtoneura simplex, I7

DIPTER E, nearly 3,000 species, 10

Dragon-flies, 55

Drone-flies, 20. 22

Dun-flies, see Gad-flies

Dust-bins, preferably open, 65,70

Dust destructor furnace, imperative, 65

Economic value of the fly, 4I

Egg-traps, domestic refuse as, 65,72

EMPIDÆ, 54

Empusa muscar, 56

Eristalis tenax, 21

Exclusion from rooms, 76

Fannia canicularis, 7

Filth-flies, 5 I scalaris, I4, I8

Fleas, 108

Flecked flesh, 29

Fly chart, the Wingate, 88

Fly-traps, 66

Forest (or spider) fly, 22

Fungus-flies, 5I

Futurist's Credo, 39

Gad-flies, 23

Garden pests, vegetarian, I7

Gargantuan jokes. 32

Gastrophulus, sce Estrus

Gentles, apparatus for breeding, 80

Gentles, green, 82 
Glossina morsitans, 62

Green-bottle flies, 20

Grey blow-flies, I9

Hamatobia stimulans, 16

Hamatopota crassicornis, 23

Hibernation, 15,80

", $\quad \begin{aligned} & \text { itulica, } 23 \\ & \text { pluvialis, } 23\end{aligned}$

HIPPOBO SCIDÆ, 22

Horse-flies, see Forest-flies

House-fly fungus, 56

House-fly, larva of, 35

House-fly, wing pattern of, 12

Hover-flies, 20

Human intestinal myiasis, 25, 26

Humble Creatures, I, 34 hydrotoea dentipes, 17

, irritans, 17

Instar, pupa, or chrysalid, 40

Larvæ, see Maggots

Lesser house-fly, larva of, 36

" , wing pattern, I2

Louse-fly, tick, or ked, 22

Lucilia Casar, 20

, sericata, 20

Lyperosia irritans, I7

Maggots, feeding in company, 36

" insectivorous, 2I

" jumping or hopping, III, II2

, myiasic possibilities, $28,37,82$

parasitic on lepidoptcra, etc, III

predaceous, 109

"rat-tail," 2I

"star-tail," 109

Meal-worms, 80

Merodon narcissi, 2 I

Messengers of peril, 78

Metamorphosis, 37

MICRODON, 22

Musca corvina, I4, I7

Muscina stabulans, I8, 27

Nostril-fly of the sheep, 4, 26, 28
Ocelli, visual importance of, 45

Odour of humanity, attracted by, 33

Estrid flies, egg-laying aggressions, 3I, 69

Estrus hominis, discredited, 28

Estrus (Gastroph:lus) equi, 27

"26

Estrus nasalis

Estrus ovis, 28

" (hypoderma) bovis, see

worble-flies

"worble-flies

lineatum, see

Onion-fly, 17

Owl-midges, moth-like, I09

Pestering flies, commoner kinds of-

cyrtoneura simplex, I7

fannia canicularis, 7

" scalaris, $\mathbf{1 8}$

musca domestica, 7

, corvina. $\mathbf{1 7}$

muscina stabulans, 18

and other ANTHOMYIDE

Poisons, effective insecticide, 73

Polietes lardaria, 18

Pond blood-worms, I08

Robber-flies, 54, 109

Root-fly, the, 17

Sarcophasa carnaria, 19

Scatophas a stercoraria, 19

Scavenging services, 78

Sccnopimus fenestralis, IIO

Sex differentiation, 45

Soldier-flies, 22, 109

Spiders, flies parasitic on, 110

Stable-fly, 12, 13, 16, 51

Stable manure, 67

Stomoxys calcitrans, 12, 13, 16, 51

STRATIOMYIDE, 22, IO9

Swallow, attracted to breed, 53

SYRPHIDE, 20

Syrpluus, 2I

TABANID E, 10, 22, scc also bloodsucking flies 
TACHINIDE, 10, 19

Therioplectes, see blood-sucking fiies

TIPULIDE, 109

Traps for flies, some ineffective, 72

Turnip-fly, a beetle, 17

Veins of wings, II

Voltairean atheism, controversy of, 5
Volucella, 21

Warning signals, flies as, 78

Westminster Hospital and myiasis, 28

Window-fly, the, I Io

Window screens, 77

Wingate's nomenclature symbols, 12

Wing patterns contrasted, 12

Worble-flies, 26, 28, 69 





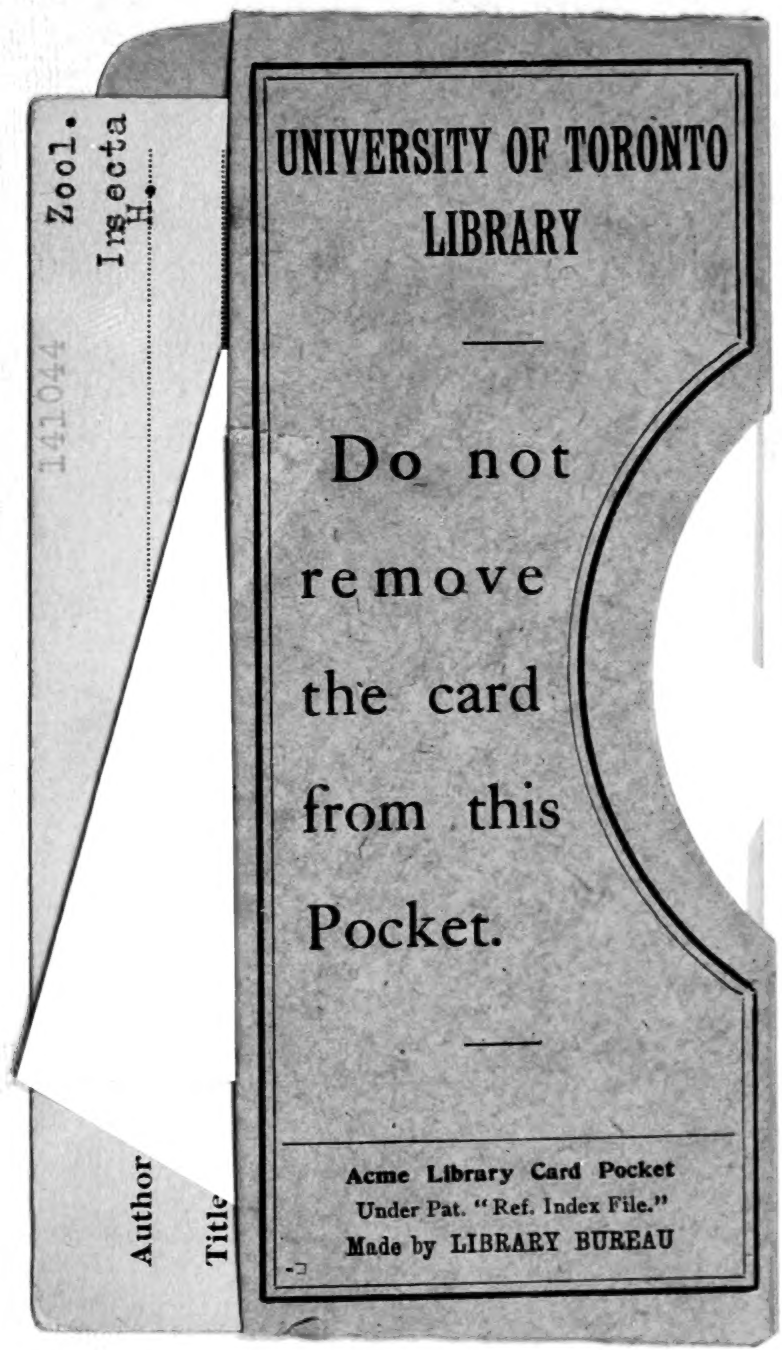




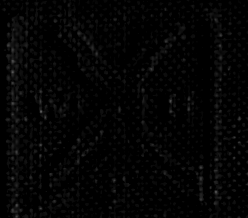

